\title{
The role of matrix metalloproteinases in cancer progression, in particular metastasis
}

Fatima A.S. Alsayad

Department of Oral and Maxillofacial Surgery, James Cook University, Townsville, Australia

Submitted: 28 March 2018

Accepted: 9 September 2018

Arch Med Sci Civil Dis 2018; 3: e124-e146

DOI: https://doi.org/10.5114/amscd.2018.81070

Copyright $\odot 2018$ Termedia \& Banach

\section{Abstract}

Cancer is a major global health concern, and is one of the leading causes of mortality in many developed countries including Australia. Most of the morbidity and mortality associated with cancer can be linked to the process of metastasis, whereby malignant cancerous cells move from their primary site to establish secondary tumours at a distant location. The capacity of cells to migrate through a tissue depends on their ability to degrade the extracellular matrix. Matrix metalloproteinases are the main protease enzymes involved in the degradation of the extracellular matrix. The release of these enzymes is important, not just for normal immune and inflammatory processes, but also for cancer.

Key words: cancer, metastasis, inflammation, matrix metalloproteinases, substance $P$.

\section{Introduction}

Cancer is a major problem worldwide, and is the leading cause of mortality in Australia [1]. Particularly in countries with aging populations, there is a potential for further increases in its incidence worldwide [2, 3]. Cancer is not only a cause of mortality, but it also has negative effects on quality of life, family relationships, functional status, and social functioning. In addition, it has a range of economic impacts, including health care costs, employability, productivity, and insurability [4].

The term neoplasm or (tumour) refers to a new growth or abnormal mass of tissue which does not obey the growth laws of a normal cell [5]. As such, they are characterized by progressive or uncontrolled proliferation of cells [6].

Neoplasms may be classified as benign or malignant. Benign neoplasms grow slowly, are enclosed in a fibrous capsule, are limited to a specific location, and are considered as non-cancerous [7]. Importantly, they do not cause death unless their location interferes with or affects vital body function [8].

By contrast, malignant neoplasms have lost the ability to control both cell proliferation and differentiation [9]. They are often fatal because the cancer cells can spread to distant sites through the bloodstream, lymphatic system, or through body spaces [10-17]. Moreover, cancer metastasis is the major reason for the failure of treatment, as well as the leading cause of mortality in individuals with malignant tumours [14, 18].

Thus, understanding the process by which tumour cells develop heterogeneity, invade local tissues, and spread to distant tissues is a major

\author{
Corresponding author: \\ Fatima A.S. Alsayad \\ Department Oral and \\ Maxillofacial Surgery \\ Medicine and Dentistry \\ college \\ James Cook University \\ Queensland, Australia \\ Phone:+61 499004085 \\ E-mail: drfatima2006@yahoo. \\ com
}


goal of cancer research. An improved understanding of the metastatic process may enable the development of more effective therapies for a variety of different cancers.

\section{Metastasis}

It is the dissemination and implantation of cancer cells at metastatic sites that has been considered the final stage in a deteriorating process, and it is the major feature of malignant tumours, which are responsible for $90 \%$ of cancer-related deaths [19]. Metastasis is the movement of tumour cells to a site that is distant from the primary tumour and the adaption to create a favourable site for tumour growth involving the interaction between tumour cells and the host microenvironment. This is governed by the same factors that directed proliferation at the primary site [13, 14, 20, 21].

The implantation of tumours at secondary sites is not merely a random process. Rather, a "seed and soil" guided event is proposed. The organpreference patterns of tumour metastasis are the product of favourable interactions between metastatic tumour cells (the "seed") and their organ microenvironment (the "soil") [22-24].

The spread of cancer cells may happen by penetration of the bloodstream, lymphatic tissue or via spaces surrounding organs [25-27]. As with benign neoplasms, malignant tumours arise because of cancer cells lacking the ability to balance cell division and cell death (apoptosis) [10, 12].

Additionally, they possess a variety of other characteristics that contribute to their metastatic potential. One of the critical first steps is that these transformed cells lose the ability to communicate and to interact with each other, which enables them to penetrate neighbouring tissues (invasion) before spreading via the bloodstream, or lymphatic system to distant sites [4, 28, 29]. Also, they can form their own new vascular supply from pre-existing vessels through the process of angiogenesis [30, 31].

Invasion is certainly a prerequisite for metastasis. In other words, without invasion there would be no metastasis [32]. Invasion usually happens before metastasis, with the tumour cells infiltrating the surrounding tissues before spreading to distant locations [16, 27, 33]. Furthermore, most cancer cells secrete proteases which enable them to break down the extracellular matrix of the surrounding tissue and thus facilitate the processes of invasion and metastasis [34-36].

Key points:

- Metastasis is responsible for $90 \%$ of cancer-related deaths.

- Metastasis is "seed and soil" guided event through interconnected stages.

- The cancer cells possess a variety of characteristics that contribute to their metastatic potential.
- Metastatic cells at a secondary site are governed by the same factors that directed proliferation at the primary site.

- Invasion is certainly a prerequisite for metastasis.

- Most cancer cells secrete proteases that are involved in the process.

\section{Mechanisms associated with metastasis}

All the stages of the metastatic process are complicated, and all are necessary for successful dissemination and implantation of the tumour in the secondary site [37]. The failure of completion of any stage entails the collapse of the overall process $[37,38]$. In addition, it is not necessary that all the steps of the metastatic stages happen in a linear way; for example, premalignant tumours can already be vascularized, while the timing of induction of the pre-metastatic niche remains elusive [39]. One key point in the formation of metastases is that the cancer cells twice must cross the endothelial cells that line blood vessels (once during intravasation and once during extravasation) [17].

Moreover, cancer cell extravasation usually occurs in small capillaries, where the cells can be physically trapped by size restriction and can then form stable attachments to endothelial cells $[17,40]$.

Furthermore, in metastasis, many pairs of ligand-receptor molecules participate in the metastatic process, including cadherins, integrins, selectins, CD44 and immuno-globulin superfamily receptors [17].

\section{The metastatic cascade}

Metastasis is often described as a 'cascade' of events, because there are multiple steps, which are interconnected, including a series of adhesive interactions and invasive processes, as well as responses to chemotactic stimuli [41].

In this section, we will provide a review of the stages involved in this process, with a focus on the extravasation step, and its significance in cancer metastasis. In addition, we will consider the mediators, the key molecules and molecular interactions involved in the complex cascade of events that lead to cancer cell metastasis.

The complex sequential manner of the metastatic cascade [39] can be summarized as follows (Figure 1) [41]:

\section{Tumour angiogenesis}

Formation of new blood vessels from pre-existing vasculature (angiogenesis) is required for the growth and metastasis of all solid tumours [42], and is a highly regulated process [43]. Moreover, angiogenesis is a significant biological process as 
(1) Angiogenesis

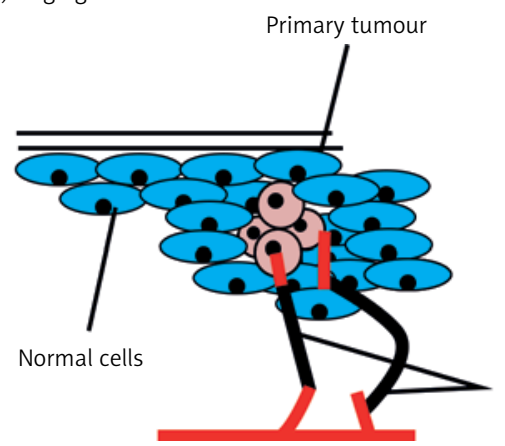

(2) De-adhesion of tumour cells

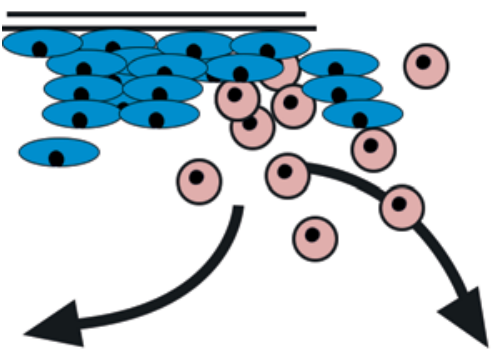

(3) Invasion of and migration through the BM and ECM and subsequent invasion of the BM of the endothelium

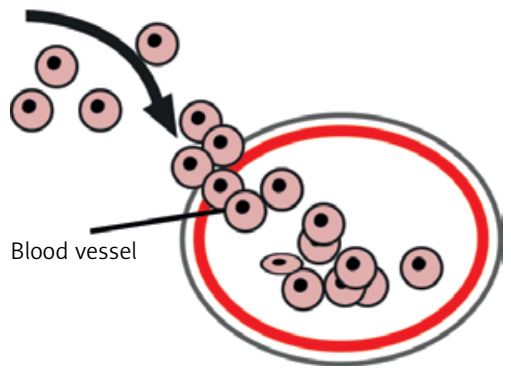

(4) Intravasation

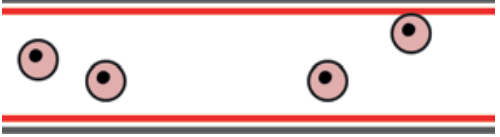

(5) Adhesion of cancer cells to endothelial cells

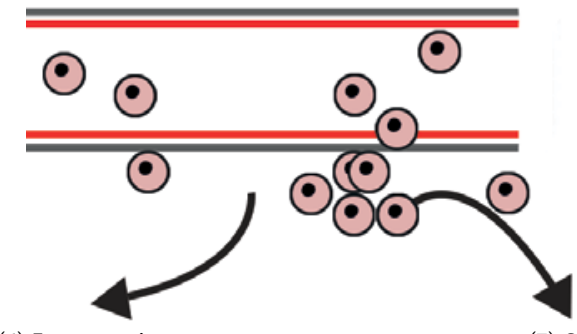

(6) Extravasation

Figure 1. The metastatic cascade [41]

part of growth and development [44], as well as pathological processes including cancer and different types of diseases [42]. Currently, it is well accepted that metastatic cancer could not progress without the formation of a blood supply to the solid primary tumour mass [41]. Additional- ly, tumour angiogenesis is one key factor in the dissemination of cancer due to the metabolic demands of tumour tissue being met through neovascularization $[45,46]$.

Angiogenesis consists of a series of steps, and depends on the balance between different molecules released by the host and tumour cells [47, 48]. When the primary vascular plexus is formed, more endothelial cells (ECs) are separated, which can form new capillaries by sprouting or by splitting from their vessel of origin in a process termed angiogenesis [49].

To stimulate angiogenesis, tumour cells and surrounding stromal cells produce soluble pro-inflammatory and pro-angiogenic cytokines, such as tumour necrosis factor $\alpha$ (TNF- $\alpha$ ), vascular endothelial growth factor (VEGF) and interleukin-8 (IL-8), which diffuse into the nearby tissues and encounter pre-existing blood vessels near the tumour [49]. Additionally, they bind to receptors located on the endothelial cells lining these blood vessels, and on the tumour cells themselves, and stimulate the production of adhesion molecules, including integrins [48], proteases such as the matrix metalloproteinases (MMPs) and plasminogen activators [41].

Many stimulators of angiogenesis have been identified, including the members of angiopoietins, platelet-derived growth factor, and members of the fibroblast growth factor (FGF) family [50]. In addition, factors that control angiogenesis include soluble growth factors, membrane-bound proteins, cell-matrix and cell-cell interactions, and many interacting systems [49]. Thus, targeting these factors, as well as adhesion molecules involved in the mechanism of angiogenesis, represents an attractive approach for cancer treatment.

\section{Disaggregation of tumour cells from the primary tumour}

Detachment of cancer cells from each other, and from the primary tumour, is the first stage in metastasis for cancerous cells to initiate their dissemination [41]. They lose their tight adhesion with the neighbouring tissue, and then change into a more invasive form, which is more mobile and can degrade any hindering structure in their way to access the blood vessels [51].

E-cadherins, mediators of cell-cell interactions, play a crucial role in epithelial cell adhesion and in the maintenance of tissue architecture [52]. In addition, cadherin molecules that are responsible for intercellular adhesion expression were found to be significantly reduced in some types of cancer associated with metastatic phenotype [53].

Also, E-cadherin mediators have a prognostic role, and could be a useful biomarker in the prognosis or predication of cancer outcome [54, 55]. Furthermore, an association between down-regu- 
lation of E-cadherin expression and a strong invasive potential has also been reported in vivo in cancers of the breast [56], nasopharynx [57], gastrointestinal tract [58], pancreas [59], lung [60], and kidney [61].

In addition to E-cadherin's role in cell adhesion, cadherin-catenin complexes are also involved in intracellular signal transduction pathways [62]. This interaction between cell adhesion and signalling functions might contribute to the mutual regulation of the cadherin-catenin complex [41].

Another adhesion molecule, $\mathrm{N}$-cadherin, was shown to exist in the most invasive and dedifferentiated breast cancer cell lines. Its expression in tumour cells induces a varied morphology and heightened movement, invasion, and metastasis potential of the cells [52].

Moreover, there is a connection between $\mathrm{N}$-cadherin and fibroblast growth factor (FGF) receptor, resulting in signals that lead to the regulation of MMP-9 [63]. In addition to a signalling function in metastasis, $\mathrm{N}$-cadherin probably supports the systemic dissemination of tumour cells by enabling circulating tumour cells to connect with the stroma and the endothelium at distant sites [52, 63].

After separation of the cancerous cells from the primary tumour, they attach to matrix components which consist of collagens, proteoglycans and glycoproteins. Further, the breaking down of the basement membranes, and remodelling of the extracellular matrix (ECM) by proteinases, facilitates intravasation of these metastatic cells into lymph or blood vessels [17, 40].

\section{Invasion of and migration through \\ the basement membrane and ECM}

Invasion and migration of cancerous cells through the basement membrane (BM) and ECM before getting inside blood vessels, is mediated by integrins and proteases, including urokinase form of plasminogen activator (UPA), MMPs and cathepsins [41, 64].

\section{Intravasation of tumour cells into the blood vessels}

Access of tumour cells to blood vessels prior to haematogenous dissemination to distant sites [64] might be affected by the specific characteristics of the blood vessels at which the intravasation occurs [64].

Studies on cancer cell intravasation have demonstrated that tumour cells are able to mechanically translocate and squeeze into the endothelial barrier by acquiring a migratory behaviour [65]. This includes the ability to orient themselves toward the blood vessels, change their shape into a more rounded form, and develop migratory pro- cesses that permit their movement [66]. Additionally, several factors for this mobility transformation have been identified, such as insulin growth factors and extracellular matrix molecules such as laminin and fibronectin [67].

Many integrins mediate tumour cell migration and invasion of the BM and its ECM [41]. For example, over-expression of $\alpha 3 \beta 1$ integrin by tumour cells contributes to the tumour cell invasion [41]. In addition, VEGF was identified as accompanying tumour associated angiogenesis, causing the formation of leaky vessels which provide easy access for intravasated cells [68].

The intravasation process could be active due to the release of chemotactic peptides and the movement of cells according to this gradient [69]. This active migration has been postulated to be a result of the ability of cancer cells to mimic some aspects of lymphocyte behaviour [69]. On the other hand, there is evidence supporting the hypothesis that intravasation is a passive mechanism. It has been postulated that the mechanical stress in the tumour overgrowth breaks the fragile, newly formed immature vessels, and pushes the tumour cells through these frail and weak barriers [69].

After the intravasation process, adhesion of the circulating tumour cells to the endothelial cell lining at the capillary bed takes place prior to extravasation and haematogenous dissemination to distant sites [70]. This occurs through adhesive interactions between cancer cells and endothelial cells involving selectins, integrins and members of the immunoglobulin superfamily (IgSF) [41, 70].

\section{Adhesion of cancer cells to the endothelial cells}

The adhesion of a circulating cancer cell to the microvasculature endothelium is a critical step in the extravasation stage, and the subsequent colonization. Cancer cells interact with many other circulating cells in the bloodstream, including platelets, monocytes, neutrophils and natural killer cells [71]. These cells can modulate the efficiency and capacity of cancerous cells for extravasation into established metastatic foci [71]. Therefore, the ability of tumour cells to form a metastatic colony correlates with their capacity to interact with and migrate through endothelial cell layers. This process involves multiple adhesive interactions between tumour cells and the endothelium [72].

\section{Extravasation}

Extravasation of cancer cells is the exit or the movement of cells out of the blood vessels or the lymphatic vessels through the endothelial cell layer, surrounding basement membrane (BM) and target organ tissue (Figure 2) [73]. 


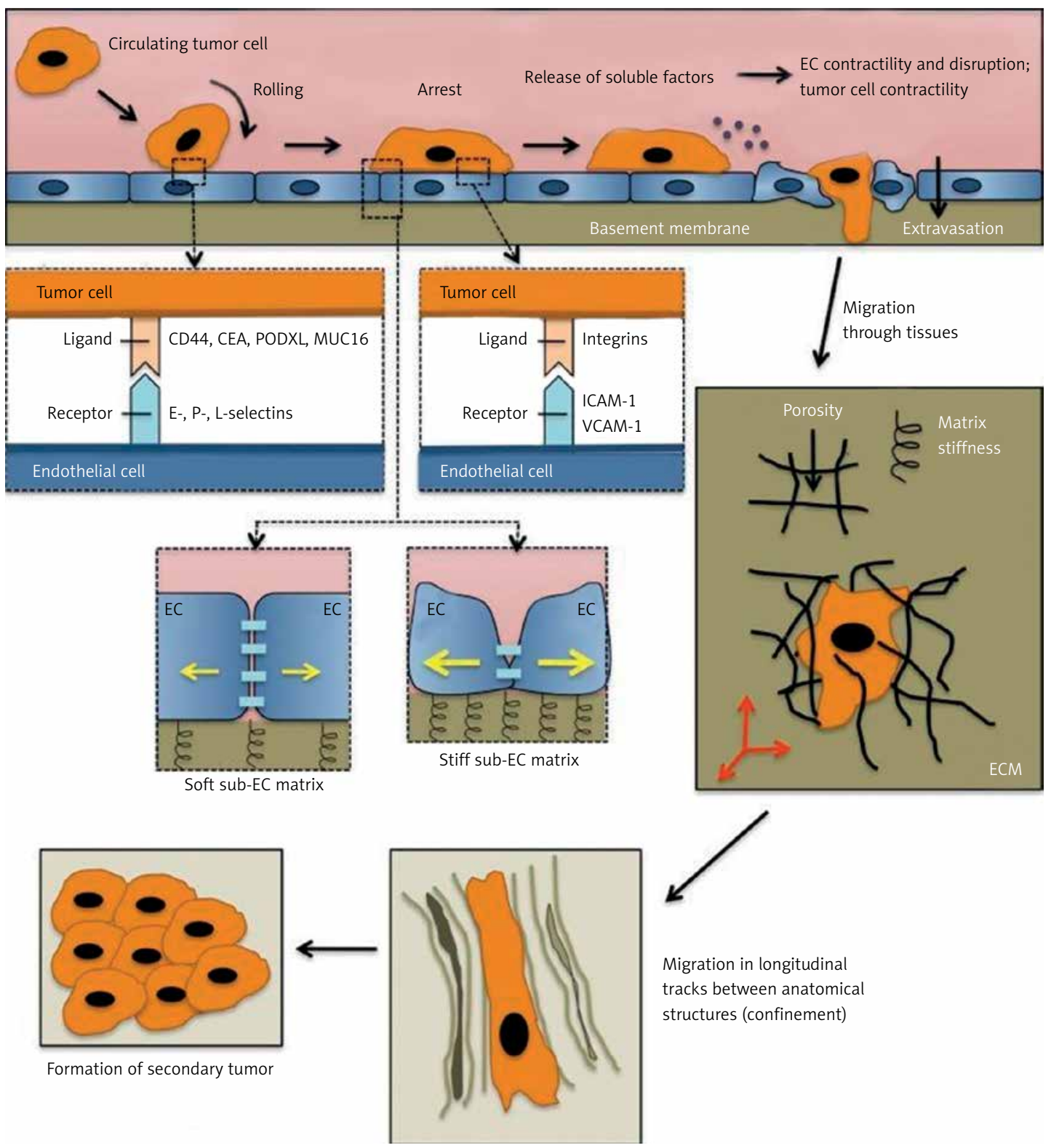

Figure 2. Stages of tumour cell extravasation [73]

It has been considered that cancer cell extravasation is the significant stage in cancer cell dissemination and implantation because adhesion, and eventually extravasation, are essential initial interactions of circulating tumour cells with distant organs [74]. In addition, cancer cells are enabled to escape from the cytotoxic environment within the circulation [74]. Indeed, the microenvironment within the circulation provides a variety not only of pro-metastatic stimuli, but also anti-metastatic stimuli that regulate the onset of organ colonisation by metastatic tumour cells [74, 75].

Migration of cancer cells throughout the body is not enough to cause distant tumours, because the cells should not be capable of surviving within environmental conditions which are totally different from those of their tissue of origin [76]. For example, blood and lymph, which are the main pathways for the spread of cancer cells, are hostile environments for cells not adapted to surviving in that environment $[76,77]$. It was estimated that only about $1 \%$ of cancer cells that enter the circulation can survive to form secondary tumours $[78,79]$.

Additionally, when the cancer cell gets in the blood circulation, it will face several stresses that reduce the chances of its survival, including the fast-flowing blood, immune response attacks by white blood cell antibodies, and apoptosis signals induced by loss of cell contact, as well as rocking of cells against the wall of blood vessels $[80,81]$. Furthermore, blood serum contains waste products and other substances that are toxic to cancer cells [27]. 
The extravasation process is in principle divided into three sequential steps: rolling, adhesion, and transmigration (diapedesis) [51].

The first step (rolling): The initial interactions of cancer cells with the vascular endothelial cells are weak [17]. Due to this loose attachment, the extravasating cells are pulled along with the bloodstream, which results in a rolling movement of the cells on the vascular surface [51].

Cancer cell interactions with endothelial cells are mediated by E-selectin, a significant element for metastasis $[82,83]$. E-selectin has been shown to be up-regulated in endothelial cells at the site of liver metastasis [84]. In addition, media from cancer lines had induced expression of E-selectin when added to endothelial culture [82, 84, 85]. Moreover, it has been revealed that cancer cells with high expression of the selectin ligands bind more efficiently and extravasate at higher rates than those with low expression [86].

It has been found that the same mechanisms are involved in the interaction of leukocytes with endothelial cells $[87,88]$. Also, leukocytes act as bridge or linker cells to facilitate the contact between tumour cells and the endothelium [89].

Further, it has been indicated that the tumour cells lack $\beta_{2}$-integrins, which are the ligand for the intercellular adhesion molecule (ICAM-1) on the endothelium. Instead, the tumour cells express ICAM-1 and adhere to neutrophil granulocytes, which then act as a linker connecting the tumour cells to the endothelium and thereby enable firm adhesion [90].

It is known that chemokines guide and regulate the migratory activity of cells. Also, it is generally accepted that tumour cells such as leukocytes use chemokines as guidance signals [91, 92]. SDF-1 $\alpha$ was the first chemokine reported to play a role in the localization of breast cancer metastases [93]. In addition, it has been shown that fractalkine (CX3CL1), a member of chemokine family, constitutively expressed by prostate carcinoma cells, can guide to the bone marrow endothelium [94, 95].

Moreover, it has been suggested that common neurotransmitter receptor, present on the endothelial surface, provides strong chemotactic signals for tumour cells $[96,97]$; and it has been demonstrated that substance P, bombesin, dopamine, and norepinephrine have a stimulatory effect on the migration of breast cancer cells [96].

The second step (adhesion): At this stage, the cells tightly attach to the endothelial cells, using receptors for this interaction that are different from those involved in the rolling process. This firm adhesion to endothelial cells requires activation of a group of endothelial cell adhesion mole- cules to achieve firm binding with their receptors (integrins) for the successful completion of extravasation [17, 89].

Furthermore, the expression of several integrins, especially of the $\beta_{2}$ subgroup, is restricted to leukocytes, so tumour cells must use different receptors or mechanisms for their adhesion to the endothelium, such as utilizing leukocytes as linker cells [51]. The expression of the $\alpha 4$ integrin has been reported in many different human tumours and tumour cell lines, especially on melanoma and sarcoma [51]. Together with the $\beta 1$ or $\beta 7$ integrin, the $\alpha 4$ integrin can act as a ligand for VCAM-1 and fibronectin [98]. In addition, animal models demonstrated that the metastatic capacity of melanoma cells is enhanced through $\alpha 4 \beta 1$ integrin interactions with VCAM-1 $[98,99]$.

Galectins, which are a group of adhesion receptors, are involved in the adhesion step as well, and in several experimental systems galectin-3 expression in cancer cells was associated with a metastatic phenotype [100].

After attachment, the mostly spherical cells spread on the endothelium and actively transmigrate through the endothelial barrier (diapedesis).

The third step of the extravasation process is called diapedesis: Following the strong adhesion, and tumour cell extravasation, the tumour cells do not leave the endothelium intact, but cause irreversible impairment of endothelium integrity after diapedesis [101]. This is understandable because the tumour cells are much larger than leukocytes and it would be difficult to squeeze between endothelial cells without any irreversible damage of this integrity [101].

Adhesion and migration were increased though stimulation by tumour necrosis factor- $\alpha$ (TNF- $\alpha$ ) and phorbol-12-myristate-13-acetate (PMA) [102]. Also, chemokine production by cancer cells can also contribute to extravasation [17]. For example, CC-chemokine ligand 2 (CCL2) produced by colon cancer cells and breast cancer cells interacts with CC-chemokine receptor 2 (CCR2) on endothelial cells (ECS) and/or on myeloid cells to increase extravasation and metastasis in the lung [103, 104]. In addition, cancer cell-derived chemokines can attract leukocytes, which facilitate the escape of cancer cells from the immune system and subsequent extravasation success of cancer cells [17].

To cross the vascular endothelium, tumour cells can take two different pathways [102, 103]. They can take either the paracellular route (junctional route), where cells move between neighbouring endothelial cells, which involves localized disruption of endothelial cell junctions [102, 103]. Alternatively, they can use the transcellular route, 
where the cells migrate through the endothelial cell body [102, 103].

Although both leucocytes and tumour cells can migrate through the two routes, different subpopulations adhere to specific routes, but the reasons for this are yet to be identified [104].

Two routes have been proposed for this step, the para-cellular route where cells can move between neighbouring endothelial cells itself [104]. To cross the vascular endothelium, leukocytes can take two different pathways. Leukocytes can take either the paracellular route and migrate through interendothelial junctions, squeezing through between adjacent endothelial cells, or leukocytes can take the transcellular route and migrate through an individual endothelial cell body.

The adhesion step imposes structural changes in migrating cells, by changing their shape into round as well as rearranging their cytoskeleton $[104,105]$. These changes also occur in the endothelial cells where an evident change of vascular endothelial cadherin has been recorded, as well as increase in vascular permeability [105].

Moreover, adhesion to endothelial cells triggers changes that activate platelet-endothelial cell adhesion molecule (PECAM) and $\mathrm{N}$ cadherin, which are demonstrated to play a major role in the diapedesis process [106]. Once migrating cells pass the endothelial layer, they are faced with two obstacles: the basement membrane of the blood vessel and extracellular matrix of the secondary site [107].

Studies have shown that leucocytes utilize MMPs to degrade extracellular matrix to advance to reach the site of the inflammation $[108,109]$. It is not clear if the cancer cells apply the same mechanism, which might seem instinctively mandatory [109]. Hence further studies are needed to investigate the role of MMP in cancer cell extravasation.

The adhesion of circulating cancer cells is a critical step in the metastatic process because they interact with many other circulating cells in the bloodstream, including platelets, monocytes, neutrophils and natural killer cells, and these cells modulate the efficiency of cancer cells to extravasate and establish metastatic foci [71].

In addition, the adhesion of circulating tumour cells to the microvasculature endothelium represents a milestone in the extravasation process. The interaction of endothelium with the neoplastic cells determines the physical point of cell exit for successful dissemination and implantation of the tumour in the secondary site $[74,75]$. Thus, metastasis should be targeted not only against tumour cells, but also against the host factors that contribute to and support the progressive growth and survival of metastatic cancer cells.

A key point in metastasis is the many pairs of ligand-receptor molecules, including cadherins, integrins, selectins, CD44, and immunoglobulin superfamily receptors, that participate in the metastatic process, and are necessary for the successful dissemination and implantation of the tumour at the secondary site [110].

Cell adhesion is primary determinant of metastasis: Cell adhesion molecules (CAMs) are membrane receptors that mediate cell-cell and cell-matrix interactions, and they are essential for transducing intracellular signals that are responsible for adhesion, migration, invasion, and organ-specific metastasis [70]. Most CAMs such as integrins, E-selectin, and P-selectin, immune-globulin superfamily (IgSF), intercellular cell adhesion molecule-1 (ICAM-1), and vascular endothelial cell adhesion molecule-1 (VCAM-1) have been studied extensively in the process of inflammation [110].

In terms of cancer, on the other hand, studies reveal that tumour cell interactions through selectins and integrins actively contribute to the metastatic spread of tumour cells [70, 111, 112]. Additionally, data show that selectins and integrins significantly link with cancer progression [113, 114]. Furthermore, there is accumulating evidence to indicate the role of selectins and integrins in cancer metastasis in numerous cancer types [70, 112-114]. Also, cancer cell interactions with platelets and leukocytes contribute to cancer cell adhesion, extravasation, and the establishment of a metastatic colony [70].

The adhesion molecules are:

\section{Integrins}

They are cell-surface receptors that mediate adhesive interactions between cells and the ECM [70]. The structure of integrins consists of two distinct chains, $\alpha$ - and $\beta$-subunits. Eight $\beta$ - and nineteen $\alpha$-integrin subunits have been identified in mammals [115]. The integrins bind to the $\mathrm{BM}$ and ECM through interaction with a variety of components, such as collagen or laminin, and are involved in both cell-ECM/BM stabilisation interactions and maintenance of the architecture of these structures [41, 70, 80]. In addition, integrins act as a transmembrane mechanical connection between extracellular contacts and the cytoskeleton inside cells [115].

As many human tumours arise from epithelial cells, integrins expressed on epithelial cells generally also exist in tumour cells [41]. Moreover, integrins are expressed on blood cells including leukocytes, T-lymphocytes, monocytes and platelets. They act as receptors for endothelial cell adhesion molecules and mediate blood cell-endothelial cell or blood cell-blood cell adhesion during the inflammatory process [41]. 
Furthermore, studies have identified a well-established role of integrin during migration and invasion. Integrins regulate cell proliferation, survival and angiogenesis, and all the processes that have been associated with cancer progression [70, 115]. Studies have also demonstrated that integrins are emerging as significant players in metastatic behaviour [70, 80], and variable integrin expression is a common characteristic of cancers, including breast [116], prostate [117], colon [118], and melanoma [119]. Additionally, evidence reveals a correlation between integrin expression levels and pathological outcomes, such as metastasis or survival of the cancer patient [80]. For example, melanomas expressing high levels of $\alpha v \beta 3$ have a poor prognosis [120].

Many integrins mediate tumour cell migration and invasion of the BM and ECM surrounding the tumour epithelium, and invasion of the BM of the endothelium of local blood vessels as well [41, 80]. For example, $\alpha v \beta 3$ mediates vascular invasion, and its binding to L1 on endothelial cells promotes melanoma cell migration towards blood vessels. Its binding to vitronectin upregulates MMP-2 expression leading to stromal degradation $[41,121]$. In addition, both $\alpha v \beta 3$ and $\alpha 3 \beta 1$ are involved in cancer cell adhesion to the BM underlying endothelium [121].

Furthermore, Integrins do not just mediate cell$\mathrm{BM}$ adhesion, but ligand binding can also lead to the activation of further intracellular signalling pathways [122], which can consequently stimulate events such as proteolysis or angiogenesis [41]. Additionally, it has been shown that the altered expression of the ECM/BM-associated integrins in carcinomas is involved in cancer metastasis, not only through tumour cell migration into the ECM and surrounding stroma involving integrin-mediated adhesion/de-adhesion events, but also through the release of proteolytic enzymes stimulated by integrin-mediated intracellular signalling events [41].

\section{Selectins}

Selectins are vascular receptors that are expressed on activated endothelial cells, and facilitate interactions of tumour cells with platelets, leukocytes, and endothelium [114]. They are three members of the selectin family, leukocyte-selectin (L-selectin), endothelium-selectin (E-selectin) and platelet-selectin (P-selectin). They have been examined as a mediator and potential facilitator of metastasis at sites where arrested tumour cells in the microvasculature have been observed [71, 123].

Further, the physiological functions of selectins are well examined in processes of inflammation, immune response, wound repair, and haemostasis [70]. L-selectin mediates fast rolling of leukocytes on endothelium, while P- and E-selectins support rolling at lower velocities [70]. However, with cancer, selectins mediate by arrest and adhesion of cancer cells, contributing to metastasis. Integrins, however, mediate the interaction between tumour cells and the surrounding environment to further participate in cancer progression [124].

Additionally, it has been demonstrated that expression of the adhesion molecule E-selectin is just up-regulated in response to inflammatory cytokines such as TNF- $\alpha$ and interleukin-1 $\beta$ (IL-1 $\beta$ ) [107]. In fact, several studies indicated the importance of pro-inflammatory cytokines for adhesion of tumour cells to the endothelium $[41,107]$. For example, increased adhesion rates of pancreatic carcinoma cells to IL- $1 \beta$ and TNF- $\alpha$ at microvascular endothelial cells and mesothelial monolayers respectively have been reported, and associated with a possible increased risk of metastasis [41].

Immunoglobulin superfamily (IgSF)

IgSF is a group of cell surface glycoproteins, comprising the immunoglobulins (IG), T cell receptors (TR) and proteins that have the common feature of having at least one Ig-like domain. IgSF members play a role in the inflammatory process and correlate with the immune system [125]. On the other hand, and due to the widespread expression of immunoglobulin superfamily proteins (IgSF) in cancer cells, they are implicated in cancer progression [126].

There are other cell adhesion molecule (CAM) categories that are known to participate in the adhesion process, including vascular cell adhesion molecule (V-CAM) and ICAM-1, that are related to the immunoglobulin superfamily as well [110]. The involvement of these endothelial molecules is receiving attention, because the expression of V-CAM and I-CAM was significantly higher in the tissue and serum of cancer patients [127, 128].

\section{Secondary tumour foci formation}

The final stage of the metastatic cascade is the development of secondary tumour foci at the target organ site [41]. Once tumour cells reach the secondary site,

i) They may be destroyed within $24 \mathrm{~h}$ as a result of apoptosis [129].

ii) They might also lie dormant (physical functions suspended or slowed down for a period of time), and possibly be activated at a future time point by, for example, the effects of host immune suppression, or

iii) They may proliferate to form secondary tumours [129].

There are some locations where metastases occur more frequently. For example, the liver, lungs, lymph nodes, brain, bone marrow and adrenal 
glands are regarded as common sites of secondary tumours, while the heart and skeletal muscle are rarely affected [130]. Because of the obvious selectivity, this leads to the seed and soil hypothesis that was put forward by Stephen Paget more than 100 years ago. Such a mechanism must exist, to an extent, in the development of secondary tumours [131].

As we have seen, the process of transportation of cancer cells, and transmigration through the blood vessels, is similar to what happens during the inflammatory process [132-136].

\section{Inflammation}

Inflammation is the immune response of the body to stimuli or injury, and is characterized by marked vascular changes, including vasodilation, increased vascular permeability, increased blood flow, and increased movement of leukocytes from the blood to the injured tissues, which are induced by the actions of various inflammatory mediators $[137,138]$.

\section{Extravasation in inflammation}

The extravasation of leukocytes is well characterized, and has been reviewed in several aspects. Comparatively little is known about the extravasation of tumour cells, which is part of the haematogenic metastasis formation [51]. Although the steps of the process are basically the same in leukocytes and tumour cells, i.e. rolling, adhesion, and transmigration (diapedesis), the molecules that are involved are different [70]. Another important difference is that leukocyte interaction with the endothelium disrupts the endothelial integrity only temporarily and reversibly, whereas tumour cell interaction leads to irreversible damage of the endothelial architecture; moreover, tumour cells utilize leukocytes for their extravasation as linkers to the endothelium [51].

Leukocyte extravasation is a sequence of events in the journey of leukocytes from the vascular lumen to the interstitial tissue which occurs in a stepwise manner [138-141]. Firstly, individual and rows of leukocytes slowly stumble along the endothelium and adhere to the endothelium. This is called pavementing, and there is a receptor- mediated mechanism [142]. After adhesion, leukocytes insert pseudopods into junctions between the endothelial cells and pass across the basement membrane to escape into extravascular space by the extravasation stage, which is the physical point of inflammatory cells to exit the blood vessels to the inflamed or irritated site [142-144].

Furthermore, leukocytes secrete proteases, such as MMPs, which are a group of proteolytic enzymes whose main function is to degrade ECM protein [145-147]. Matrix metalloproteinases are regarded as key molecules in inflammation, and up-regulated expression of MMP members is often associated with the presence of inflammation [146]. In addition, studies have revealed that inflammatory cells can induce the expression of MMPs, which are crucial for all stages of the inflammatory process, from tissue repair and foreign body elimination to activating cytokines [148, 149].

On the other hand, MMPs have also been implicated in cancer progression and invasion, and are highly expressed in a variety of cancers [150]. In addition, studies have suggested that MMPs induced by inflammatory cells promote angiogenesis, a significant requirement in tumour invasion [151-153]. Thus, there may be common mechanisms associated with inflammation and metastatic tumour development including the chemical mediators that facilitate these processes.

\section{Inflammation and cancer correlation}

There is evidence to support the concept that chronic inflammation and continuous irritation participate in cancer development and progression [154-156]. Hanahan and Weinberg identified inflammation as the seventh hallmark of cancer [157].

There is research which indicated that inflammation highlights several aspects of tumour growth, survival and, most significantly, metastasis [157]. In addition, there are data indicating that many molecules, and their activities, are implicated in a link between an inflammatory microenvironment and tumour progression [158, 159]. This might be due to the inflammatory cells and immune-modulatory mediators, such as histamine, serotonin, bradykinin and SP, which may impact on cancer promotion by secreting cytokines, chemokines, proteases and growth factors which induce proliferation and invasiveness of cancer cells [158, 160, 161].

Further, both interleukin-31 (IL-31) and interleukin-33 (IL-33), which are derived from mast cell proteases, are implicated in cancer pathogenesis too [162]. There is evidence to support the concept that the presence of both inflammatory cells and immune-modulatory mediators (IL-31 and IL-33) in the tumour microenvironment is implicated in tumour progression and metastasis. For example, elevated expression of IL-33 has been shown in tumour tissues from colorectal cancer (CRC) patients [162, 163].

Additionally, population-based studies demonstrated that $25 \%$ of human cancer cases are related to chronic inflammation, and almost every cancer type is infiltrated with, or surrounded by, inflammatory cells [134]. Thus, the use of anti-inflammatory 
drugs, such as steroids and aspirin, may be helpful in the prevention or reduced incidence of several types of cancer. They may also highlight the key role of inflammation in cancer [164-166].

In terms of the potential role that inflammatory mediators play in cancer promotion and progression, there are MMPs and the pro-inflammatory peptide, SP.

\section{Matrix metalloproteinases}

Matrix metalloproteinases are a large family of calcium-dependent zinc-containing endopeptidases that are responsible for tissue remodelling and degradation of the ECM. Their substrates include collagens, elastins, gelatin, matrix glycoproteins, and proteoglycan [167]. The 23 expressed MMPs in humans are regulated by hormones, growth factors, and cytokines [167].

The general structure of MMPs shows three domains that are common to almost all MMPs: the pro-peptide, the catalytic domain, and the hemopexin-like C-terminal domain, which is linked to the catalytic domain via a flexible hinge region [168] (Figure $3 \mathrm{~A}$ ).

These enzymes are expressed as zymogens (inactive), and are subsequently processed by other proteolytic enzymes (such as serine proteases, furin, plasmin, and others) to generate the active forms [169].

Except for membrane-type (MT)-MMPs, all MMPs also share the characteristic of being activated in the extracellular space $[170,171]$. The MMPs can also be grouped into eight classes, based on their domain structure. They contain an N-terminal pre-domain that is required for the correct secretion of these enzymes and share structural similarities; however, they differ from each other in their expression profiles and choice of substrate [167].

All MMPs share these characteristics [167]:

- they degrade proteins of the ECM of tissues,

- they contain zinc in the active site,

- they require calcium for their stability, and they function only at a neutral $\mathrm{pH}$.

Additionally, MMPs are excreted by a variety of connective tissue and pro-inflammatory cells (Figure $3 \mathrm{~B}$ ), including fibroblasts, osteoblasts, endothelial cells, macrophages, neutrophils, and lymphocytes [172].

Further, based on their substrate specificity and structural characteristics, the MMPs are further divided into several subclasses: collagenases (MMP-1, -8, -13), gelatinases (MMP-2, -9), stromelysins (MMP-3, -10, -11), matrilysin (MMP- 7), elastase (MMP-12), and MT-MMPs (MMP-14, -15, $-16,-17)[170,171]$.

Of the MMPs, a specific subset, namely the gelatinases (MMP-2 and MMP-9), plays a crucial role in a wide variety of physiological and pathological conditions [167, 173, 174]. Amongst them, their potential role in cancer has generated most interest, and has been extensively studied.

\section{Gelatinases (MMP-2 and MMP-9)}

Matrix metalloproteinase-2 (MMP-2) and MMP9 are called gelatinase $A$ and gelatinase $B$ respectively, because gelatine was identified as one of the key substrates for these two enzymes [167]. MMP-2 and MMP-9 are highly similar enzymes in many aspects, but significant differences exist in the regulation of expression, glycosylation, proenzyme activation and substrate selectivity [167]. For example, the 92-kDa MMP-9 contains two $\mathrm{N}$-glycosylated sites in the prodomain and the catalytic domain [175]. MMP-9 expression is observed in normal leukocytes as well as in transformed cells [167]. Also, MMP-9 exists in plasma as a monomer, complexed with neutrophil lipocalin, and as a dimer. In adults, the expression of MMP-9 is restricted to neutrophils [176] and eosinophils [177]. However, MMP-2 is a $72-k D a$ protein, which is strictly monomeric and, in general, is produced constitutively (produced in a relatively constant amount in all cells) by a wide range of cell types including endothelial cells and macrophages [178].

"Despite their largely overlapping functions, MMP-2 and MMP-9 may even have opposing biological activity as illustrated by the finding that MMP-2 promotes platelet aggregation, but MMP-9 inhibits the same process." [179].

\section{Gelatinase substrates}

Gelatinase substrates involve a wide collection of proteins, including ECM proteins, proteinases, proteinase inhibitors, blood clotting factors, chemotactic molecules, both latent growth factors and growth factor binding proteins, cell surface receptors, adhesion molecules and even intracellular substrate [167]. In addition, gelatinases can also break down other ECM proteins such as type IV collagen, elastin, vitronectin, and aggrecan [180]. However, currently, the relevance of these events in vivo is unclear, but the cleavage sequences of both MMP-2 and MMP-9 have been mapped with the substrate phage [181, 182].

The substrate specificities of MMP-2 and MMP9 are similar but not identical and the minor differences in catalytic domain have functional consequences in the gelatinases' substrate selectivity [167].

It has been found that in the human brain, neurons produce MMP-9 in regions where collagen is not present [183]. As a result, the ability of the enzyme to degrade bioactive peptides was 


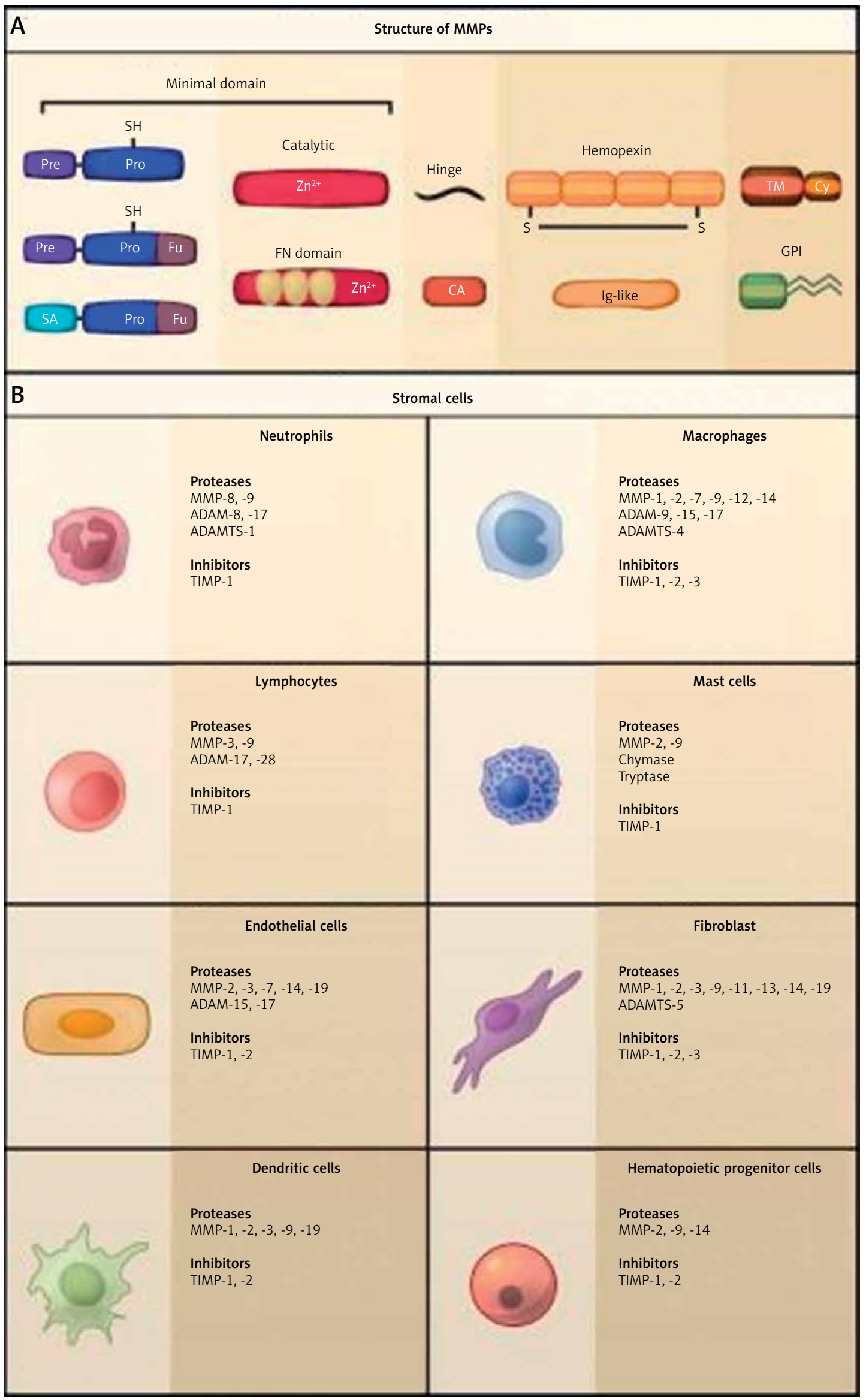

Figure 3. MMP composition and expression in the stroma [168] 
examined, particularly with respect to the tachykinin peptides (SP, neurokinin A, neurokinin $B$, and kassinin) [183]. Additionally, at the same time, It has been shown that the active form of MMP-9 degraded SP at a 30-fold greater rate than the previously reported value for a representative collagen-derived peptide [183].

\section{Proenzyme activation}

As I mentioned before, the gelatinases are secreted as inactive pro-forms, and they need to be activated externally for full catalytic activity. Activation occurs by disruption of a $\mathrm{Zn}^{2+}$-cysteine bond, either by removing the prodomain or by modifying the cysteine residue in the prodomain [184]. The activation of the gelatinases takes place on the cell surface or in the extracellular milieu $[185,186]$. Further, a number of proteases can activate gelatinases in vitro (dissolution) and in vivo (bioavailability), suggesting that there is a significant crosstalk between different protease systems [167].

\section{Regulation of gelatinase}

To avoid and prevent unwanted tissue damage, it is very important to carefully control the protease activity. For this reason, protease activity is typically regulated at many levels, including transcription, secretion, activation, and by the action of proteinase inhibitors (TIMPs), which are either natural or synthetic gelatinase inhibitors [167].

Natural TIMP proteins are significant endogenous regulators of MMP activity in tissues, and act by forming tightly bound inhibitory complexes with MMPs [187]. Additionally, natural TIMP proteins are produced by a variety of cell types, and are induced or constitutively expressed by most tissues and body fluids [188]. Furthermore, TIMP-1 works as a natural inhibitor of MMP-9 (146), whilst TIMP-2 is an inhibitor of MMP-2 [189]. Thus, a balance between MMP and TIMP activities is involved in both normal and pathological events such as wound healing, tissue remodelling, angiogenesis, invasion, tumorigenesis and metastasis [167].

\section{Physiological and pathological roles of gelatinases}

It has been shown that gelatinases play a role in a wide variety of physiological [173] and pathological conditions [174]. During the natural reproduction process, the cells of the implanting embryo secrete gelatinases and other MMPs which are required for this natural invasive process. Matrix degradation and remodelling occur during reproduction, growth and development [173]. In addition, the gelatinases participate in wound healing (physiological process) [190], and are typ- ically expressed from the beginning to the end of the healing process [191].

On the other hand, when gelatinases are present at too high a level, for too long, or in the wrong places, and their activity becomes uncontrolled, they begin to degrade proteins that are not their normal substrates [192]. This can result in off-target destruction of proteins, such as growth factors, receptors and ECM proteins, that are essential for normal physiological activity, and so they eventually lead to pathological conditions [192, 193].

Increased gelatinase activity has been observed in a variety of pathological conditions including cancer, inflammatory disorders, infective diseases, degenerative diseases of the brain and vascular diseases [193, 194]. Thus, the old paradigm that gelatinase's role is restricted to matrix digestion might not be the case. There is new evidence suggesting that both MMP-2 and MMP-9, collectively, are important in the pathogenesis of inflammatory, infectious, and neoplastic diseases in many organs $[167,195]$.

\section{Gelatinases and inflammation}

Several studies have indicated that MMPs, including gelatinases, represent a marker of inflammation because they regulate several functions related to inflammation, including bioavailability and activity of inflammatory cytokines and chemokines [196]. Although MMP-9 is expressed by neutrophils and inflammatory stimuli, MMP-9 expression can be stimulated by other cells including endothelial cells, alveolar cells, macrophages, fibroblasts, and other connective tissue cells [197].

Additionally, leukocytes have large amounts of protease-containing granules, which are rapidly excreted and delivered to the extracellular space after leukocyte activation [198]. One of these granule types, called gelatinase granules, also contains integrins, which are one of key players in the regulation of leukocyte migration in inflammation [198, 199].

Although the extracellular matrix is a key substrate for the gelatinases, these enzymes also can degrade other substrates such as cytokines and chemokines, thereby resulting in different physiological and pathological processes [200]. In other words, chemokine and cytokine cleavage by gelatinases can have varying impacts on their biological properties, ranging from potentiation and inactivation, to antagonist formation [200].

Recent studies suggest that both MMP-2 and MMP-9 have certain chemokines and cytokines as their substrates, which act as mediators and regulators of inflammation. Also, both MMP-2 and MMP-9 have a wide range of pro- and anti-inflammatory effects on leukocytes, endothelial cells and other cell types [201]. 
Moreover, cytokines, including IL-1, TNF- $\alpha$, and transforming growth factor $\alpha$ (TGF- $\alpha$ ), are likely to regulate genes of MMP expression that regulate the migratory activity of inflammatory cells [184]. Additionally, MMP-9 can cleave the inactive membrane-bound forms of TNF- $\alpha$ and transforming growth factor- $\beta$ (TGF- $\beta$ ) to generate their corresponding active forms, which in turn mediate the expression of adhesion molecules and promote the migration of cells [191, 202].

Similarly, both gelatinases can generate the active form of IL-1 $\beta$ from its inactive pro-form [203]. Further, signals that upregulate and activate MMP expression can also include the production of proinflammatory cytokines (such as TNF- $\alpha$, IL-1, IL-4 and (L-6), and integrin binding is also a significant step for leukocyte migration [204].

The MMP is highly expressed in any disease or condition that is associated with inflammation, and proteolysis is considered a hallmark of the inflammatory process [205]. In addition, several MMP inhibitors are used as anti-inflammatory drugs in periodontal and vascular diseases, acting through limiting MMP production or activation $[206,207]$. Thus, anti-inflammatory therapy is still the mainstay and the requirement in the control of both the inflammatory process and inflammatory mediators [206].

Tetracycline: Interestingly, studies have demonstrated that tetracyclines, in addition to their antimicrobial activity, inhibit inflammatory cell migration to sites of inflammation and also act as MMP inhibitors. The ability of tetracycline to inhibit MMPs is independent of their anti-microbial activity [208]. Tetracycline act on two levels: they suppress gelatinase expression [209], and directly inhibit gelatinase activity through a zinc chelating (removing) effect [208]. Thus, tetracycline derivatives have entered clinical trials as MMP inhibitors [210].

The first evidence that MMPs, including gelatinase, might contribute to cancer development and progression derives from the field of inflammation. The role of chronic inflammation in carcinogenesis was examined via several epidemiological studies looking at pro-inflammatory mediators, along with other factors involved in the inflammatory response [157, 211].

For this reason, anti-inflammatory therapy is still a mainstay in the treatment of equine joint disease (Goodrich and Nixon 2006). Nonsteroidal anti-inflammatory drugs (NSAIDs) are a common first line treatment in joint disorders that require alleviation of pain and control of inflammation.

\section{Gelatinases and cancer}

Cancer studies have found that MMPs, including gelatinases, can regulate multiple cellular functions including cell growth, apoptosis, angiogenesis, invasion, and metastasis by cleaving growth factor precursors, cell adhesion molecules and other bioactive proteins, and critical molecules in these processes [153, 172, 212].

Furthermore, studies have demonstrated that many malignant cells produce both MMP-2 and MMP-9 [213, 214]. Both MMP-2 and MMP-9 have certain chemokines and cytokines as their substrates, that act as mediators and regulators of metastatic processes; in addition, they have a wide range of pro- and anti-inflammatory effects on leukocytes, tumour cells, endothelial cells and other cell types [201]. As tumours consist of cancer cells and stroma, cancer cells may be the source of gelatinases in some cases, but in most cases, only stromal cells express gelatinases [215].

The chronic inflammation associated with some cancers can further stimulate cancer progression due to the release of MMPs from the inflammatory cells too $[167,215]$. Expression of MMP-2 and MMP-9 has been observed in cancers of the breast, colon, lung, skin, ovary and prostate [172]. Also, with increased gelatinase expression in these cancers types, there is an increase in invasiveness and metastasis in addition to a decrease in overall survival of cancer patients [172].

Indeed, increased gelatinase expression may be dependent on the stage of the cancer. For example, in melanoma, increased expression of MMP-9 is found in the early stage of cancer, but the opposite is true at a late stage [216]. Meanwhile, in breast and colon cancer, MMP-9 expression has been correlated with the survival and formation of distant metastases [217-220]. Further, MMP-9 has been regarded as a prognostic marker and as a target for therapeutic intervention in cancer [221].

Additionally, there are several interactions between tumour cells and the tumour microenvironment, which involve ECM, growth factors and cytokines associated with ECM, as well as surrounding cells (endothelial cells, fibroblasts, macrophages, mast cells, neutrophils, pericytes and adipocytes) $[222,223]$.

Also, it has been found that cancer cells typically migrate in response to migratory signals and this cellular response can be either non-directional movement (chemokinesis) or directed migration along a chemical concentration gradient of the signal inducer (chemotaxis) [167].

Gelatinases and cell adhesion, migration, and epithelial to mesenchymal transition: The movement of cells is highly related to the MMPs' proteolytic activity, a disintegrin and metalloproteinase (ADAMs), regulating the dynamic ECM-cell and cell-cell interactions during migration $[153,172]$. 
The main functions of gelatinase in cell migration and invasion are degradation of ECM molecules, such as collagen type IV and laminin-5 (an extracellular matrix substrate for cell adhesion and migration); disruption of cell-matrix adhesion; disruption of cell-cell interaction; and exposure of cryptic migration promoting sites. In addition, there is cleavage of matrix-associated latent factors [224] (Figure 4).

A recent study reported that hyaluronan (hyaluronic acid), which is widely distributed throughout connective tissue, promotes cancer cell migration by increasing matrix metalloproteinase secretion, and specifically increased levels of the active form of MMP-2, through Rho kinase-mediated signalling [225].

Moreover, several integrins play an active role in regulation of cell migration because they can serve as substrates for MMPs [226]. It has been suggested that integrin $\alpha 3 \beta 1$-mediated interaction with laminin-5 stimulates adhesion, migration and invasion of malignant glioma cells [227]. Hence, inhibition of the association of gelatinases with cell-surface integrin appears to offer a highly specific means to target these enzymes without inhibiting their catalytic activity in multiple cell types including endothelial cells, tumour cells and leukocytes [152, 167].

Furthermore, the signals that upregulate the expression and activation of MMPs involve the production of pro-inflammatory cytokines and integrin binding [204]. Therefore, it is plausible that inhibition of MMP activity through control of its proteolytic activity at the cell surface can greatly reduce the migration and invasion of cells by blocking the production of pro-inflammatory cytokines [228].

Morozevich et al. have demonstrated for the first time that $\alpha 5 \beta 1$ integrin promotes and controls invasion of breast carcinoma cells by regulation of MMP-2 collagenase expression. This can occur either through signalling pathways or by direct recruitment of MMP-2 to the cell surface [229]. In addition, Morozevich et al. have reported that inhibition of the invasiveness of these cells in vitro, associated with down-regulation of $\alpha 5 \beta 1$ integrin, occurs through inhibition of the expression and secretion of MMP-2 [229].

Thus, it is evident that there are complex interactions between MMPs and a variety of other inflammatory factors. As such, some of their roles in inflammation and cancer are still hypothetical [167]. Because the role of MMPs, including gelatinase, in extravasation are poorly understood, further studies need to be performed to see if gelatinase is regulated by the same factors that control the adhesion process.

Key points:

- Gelatinases have certain chemokines and cytokines as their substrates which act as mediators and regulators of inflammation and metastatic processes.

- Chronic inflammation associated with some cancers can further stimulate cancer progression due to the release of MMPs.

- Gelatinases have the ability to regulate multiple cellular functions including cell growth, apoptosis, angiogenesis, invasion, and metastasis by cleaving growth factor precursors and cell adhesion molecules.

- Gelatinases have a wide range of pro- and anti-inflammatory effects on leukocytes, tumour cells, and endothelial cells.

Several integrins play an active role in regulation of cell migration because they can serve as substrates for MMPs.

\section{Substance $P$}

Substance $P$ is a neuropeptide from the tachykinin family, which is widely distributed in both the

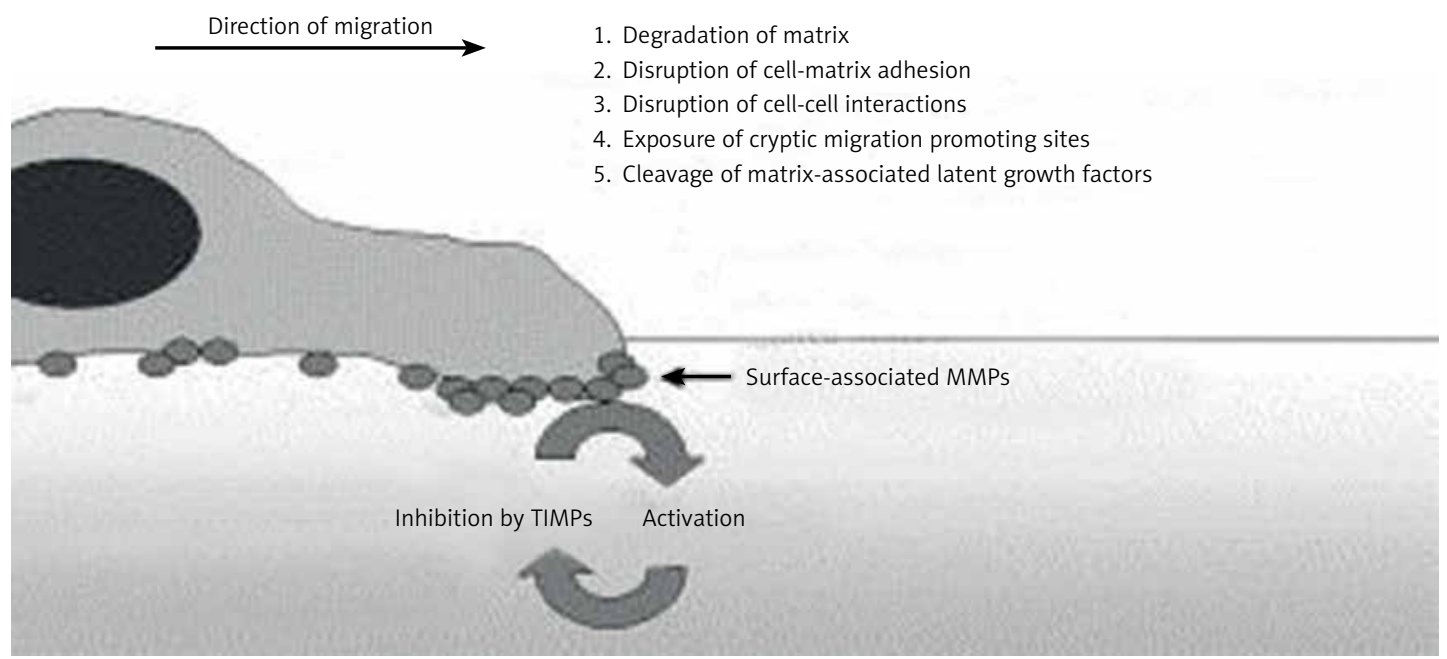

Figure 4. Functions of MMPs in cell migration and invasion [167] 
central and peripheral nervous systems. A variety of biological functions in the central nervous system, including emotional behaviour, pain perception, stress, depression, anxiety, emesis, migraine, and alcohol addiction are linked to the release of SP [195, 230].

In the peripheral nervous system and other tissues, SP acts as a local hormone (tachykinin), and causes hypotension and vasodilatation and may cause contraction of smooth muscles [231, 232]. In addition, it is thought to be involved in the regulation of respiratory mechanisms, regulation of the cardiovascular system, sensory perception, in neuronal survival and degeneration, sensory perception, movement control, gastric motility, salivation and micturition [233, 234].

Substance $P$ is also involved in multiple processes including inflammation and metastatic dissemination after binding to the tachykinin NK-1 (NK1) receptors [235].

\section{Substance $P$ and inflammation}

Over the past two decades, SP has been identified as a significant mediator in the development and progression of inflammation [236-238]. It acts as a vasoactive mediator, increasing vascular permeability and mediating the function of inflammatory cells. These impacts, collectively termed neurogenic inflammation, comprise microvascular plasma leakage, neutrophil recruitment, and inflammatory mediator synthesis, as well as increasing the vascular permeability and mediating the function of inflammatory cells [234, 239-241].

In addition, there are data indicating that SP participates in inflammation by interacting with the NK-1 receptor expressed in nerves (excitatory neurons and secretory cells) and inflammatory cells, such as macrophages, mast cells and T cells. The activation of these cells results in the release of cytokines and chemokines as active factors, as well as other neuropeptides that modulate inflammation [195, 236]. Also, there is increasing evidence that SP modulates the activities of several different leukocytes that characterize both acute and chronic inflammatory responses [239, 242, 243].

Furthermore, there is a large body of evidence demonstrating that SP possesses a variety of potent effects, including the production of cytokines, such as TNF- $\alpha$, IL-1, IL-4 and IL-6 [244, 245]; SP selectively activates TNF- $\alpha$ synthesis in mast cells too [246].

Moreover, SP stimulates the release of TNF- $\alpha$, which mediates the expression of such adhesion molecules as E-selectin, ICAM-1 and VCAM-1 on vascular endothelial cells, thereby leading to leukocyte migration [241, 247, 248]. Additionally, SP may play a role in the pathogenesis of such di- verse diseases as arthritis, asthma, and inflammatory bowel disease [249].

\section{Substance $\mathrm{P}$ and cancer}

Numerous studies have reported the involvement of the substance $P(\mathrm{SP})$ /neurokinin (NK)-1 receptor complex in cancer [161, 250, 251]. In addition, it has been demonstrated by many studies that SP acts via NK-1R as a mitogen on several human cancer cell lines such as glioma, neuroblastoma, retinoblastoma, laryngeal carcinoma, and melanoma [161, 252, 253]. Further, its presence in the tumour microenvironment strongly suggests a role for the SP/NK-1R complex in tumour development and progression [254, 255].

Also, NK-1R, a receptor of SP, is overexpressed not only in several normal cells [254, 256], but also in neoplastic cell types [252, 254, 257]. It is also known that malignant tissues express more NK-1 receptors compared to benign tissues. Additionally, the tumour cells that express most malignant phenotypes show increased NK-1 receptor expression [161].

There are studies that demonstrate that substance P, acting via the NK1 receptor, probably plays a role in several biological functions related to cancer including angiogenesis, invasion and metastasis [161].

Moreover, substance $P$ has been implicated as a mediator in cancer cell extravasation through the blood-brain barrier (BBB) to form cerebral metastasis [258].

Also, it has been reported that SP is involved in pancreatic cancer perineural invasion, and that SP induces cancer cell proliferation and invasion, as well as the expression of MMP-2 in pancreatic cancer cells [161].

Activation of the neurokinin-1 receptor (NK-1R) by substance $P$ initiates several intracellular signalling pathways, including the nuclear factor- $\kappa \mathrm{B}$

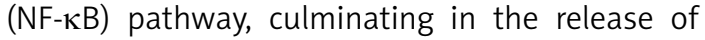
pro-inflammatory cytokines such as IL-1 $\beta$ and TNF $[235,259]$. IL-1 $\beta$ and TNF, in turn, upregulate expression of the adhesion molecules involved in extravasation [260]; blocking the NK-1 receptor has been shown to reduce expression of TNF [260].

Furthermore, the combination of SP and insulin-like growth factor-1 (IGF-1) significantly increased the number of cells attached to the fibronectin matrix, and increased the expression of integrin $\alpha 5$ [261].

Previous work in this laboratory (M. Elhousiny, unpublished data) has shown that SP can increase the expression of integrin molecules in cancer cells, accompanied by an increase in adhesion to endothelial cells. Additionally, and because integrins play an active role in regulation of cell migration, they can serve as substrates for MMPs, which 
might upregulate and activate MMPs. Blocking the NK-1 receptor reduced the expression of the integrin, and inhibited adhesion of the cells that upregulate MMP expression. Also, inhibition of the NK-1 receptor may potentially block the release and activity of MMPs, and subsequently might slow metastasis.

Hence, there is a need for more research to explore and identify the role of MMPs in cancer promotion and progression. In particular, examining the role of substance $P$ in cell adhesion and migration could mean that neurokinin-1 receptor antagonists could represent a novel and promising approach and access for treating patients with cancer. Key points:

- SP acts as a vasoactive mediator, increasing vascular permeability and mediating the function of inflammatory cells.

- SP produces cytokines, such as TNF- $\alpha$, IL-1, IL-4 and IL-6.

- A receptor of SP is overexpressed in several normal and neoplastic cell types.

- SP stimulates the release of TNF- $\alpha$, which mediates the expression of such adhesion molecules as E-selectin, ICAM-1 and VCAM-1 on vascular endothelial cells, thereby leading to leukocyte migration.

SP via the NK-1 receptor can increase expression of integrin molecules in cancer cells.

\section{Conclusions}

Cancer is probably the most devastating and heterogeneous disease and is a major cause of mortality in Australia. Metastasis is the process used by cancer cells to spread throughout the body and is associated with an increase in mortality for several cancers. Inflammation has been closely linked with cancer. The process of translocation of cancer cells and transmigration through the blood vessels is similar to what is seen with immune cells during the inflammatory process, and it is possible that inhibiting inflammation can reduce cancer progression. Matrix metalloproteinases are the main proteases that have been associated with inflammatory processes as well as cancer cell metastasis and are involved in degradation of the extracellular matrix. Substance $P$ is a neuropeptide involved in multiple processes including inflammation and metastatic dissemination. In addition, SP via the NK-1 receptor can increase expression of integrin molecules in cancer cells, and that might upregulate and activate MMPs. Blocking the action of SP via the NK-1 receptor may block the activity of MMPs and consequently slow metastasis. Thus, the development of antagonist molecules of the NK-1 receptor represents an important opportunity for exploiting these molecules as novel therapeutic agents.

\section{Conflict of interest}

The authors declare no conflict of interest.

\section{References}

1. Randall D, Degenhardt L, Vajdic CM, et al. Increasing cancer mortality among opioid-dependent persons in Australia: a new public health challenge for a disadvantaged population. Aust N Z J Public Health 2011; 35: 220-5.

2. Ferlay J, Soerjomataram I, Dikshit R, et al. Cancer incidence and mortality worldwide: sources, methods and major patterns in GLOBOCAN 2012. Int I Cancer 2015; 136: E359-86.

3. Torre LA, Bray F, Siegel RL, Ferlay J, Lortet-Tieulent J, Jemal A. Global cancer statistics, 2012. CA: Cancer J Clin 2015; 65: 87-108.

4. Cotran R, Kumar V, Collins T. Robbins Pathologic Basis of Disease. $6^{\text {th }}$ ed. 1999; 86.

5. DiGiovanni J. Multistage carcinogenesis in mouse skin. Pharmacol Ther 1992; 54: 63-128.

6. Resende RR, Ulrich H, SpringerLink. Trends in Stem Cell Proliferation and Cancer Research. S.l.: Springer Netherlands 2013.

7. Koten JW, Neijt JP, Zonnenberg BA, Den Otter W. The difference between benign and malignant tumours explained with the 4-mutation paradigm for carcinogenesis. Anticancer Res 1993; 13: 1179-82.

8. Berggoetz B. Benign tumors should just be left alone, right? Indianapolis Star 2007.

9. Neoplasms; Research from Roosevelt Hospital broadens understanding of neoplasms. Clinical Oncology Week 2009.

10. Bennis M, Tiret E, Matzel KE, et al. Malignant Tumours. Springer, Berlin Heidelberg 2008; 193-234.

11. de Krijger I, Mekenkamp LJM, Punt CJA, Nagtegaal ID. MicroRNAs in colorectal cancer metastasis. J Pathol 2011; 224: 438-47.

12. Dudjak LA. Cancer metastasis. Semin Oncol Nurs 1992; 8: $40-50$.

13. Fidler IJ. The organ microenvironment and cancer metastasis. Differantation 2002; 70: 498-505.

14. Fidler IJ, Kripke ML. The challenge of targeting metastasis. Cancer Metastasis Rev 2015; 34: 635-41.

15. Labelle M, Hynes RO. The initial hours of metastasis: the importance of cooperative host-tumor cell interactions during hematogenous dissemination. Cancer Discov 2012; 2: 1091-9.

16. Nicolson GL. Cancer metastasis. BBA Rev Cancer 1982; 695: 113-76.

17. Reymond N, d'Água BB, Ridley AJ. Crossing the endothelial barrier during metastasis. Nat Rev Cancer 2013; 13: 858-70.

18. Shi M, Liu D, Duan H, Shen B, Guo N. Metastasis-related miRNAs, active players in breast cancer invasion, and metastasis. Cancer Metastasis Rev 2010; 29: 785-99.

19. Gao P, Xing AY, Zhou GY, et al. The molecular mechanism of microRNA-145 to suppress invasion-metastasis cascade in gastric cancer. Oncogene 2013; 32: 491-501.

20. Bos PD, Massagué J, Nguyen DX. Metastasis: from dissemination to organ-specific colonization. Nat Rev Cancer 2009; 9: 274-84.

21. Fidler IJ. Timeline: the pathogenesis of cancer metastasis: the 'seed and soil' hypothesis revisited. Nat Rev Cancer 2003; 3: 453-8. 
22. Fokas E, Engenhart-Cabillic R, Daniilidis K, Rose F. An HX. Metastasis: the seed and soil theory gains identity. Cancer Metastasis Rev 2007; 26: 705-15.

23. Langley RR, Fidler IJ. The seed and soil hypothesis revisited - the role of tumor - stroma interactions in metastasis to different organs. Int J Cancer 2011; 128: 2527-35.

24. Lisanti MP, Martinez-Outschoorn UE, Lin Z, et al. Hydrogen peroxide fuels aging, inflammation, cancer metabolism and metastasis: the seed and soil also needs "fertilizer". Cell Cycle 2011; 10: 2440-9.

25. Bosman FT, Meade-Tollin LC, Noorden CJF. Metastasis. Am Sci 1998; 86: 130.

26. Dan W. Metastasis. New Coin 2011; 47: 19.

27. Oppenheimer SB. Cellular basis of cancer metastasis: a review of fundamentals and new advances. Acta Histochem 2006; 108: 327-34.

28. Cornelis JFVN, Meade-Tollin LC, Bosman FT. Metastasis: the spread of cancer cells to distant sites implies a complex series of cellular abnormalities caused, in part, by genetic aberrations. Am Sci 1998; 86: 130-41.

29. Noorden vCJF, Meade-Tollin LC, Bosman FT. Metastasis. Am Sci 1998; 86: 130-41.

30. Senger DR, Davis GE. Angiogenesis. Cold Spring Harb Perspect Biol 2011; 3: a005090.

31. Zhao Q, Li Z. Angiogenesis. BioMed Res Int 2015; 2015 : 135861-2.

32. Wittekind C, Neid M. Cancer invasion and metastasis. Oncology 2005; 69 Suppl 1: 14-6.

33. Toh $\mathrm{Y}$, Nicolson GL. Identification and characterization of metastasis-associated gene/protein 1 (MTA1). Cancer Metastasis Rev 2014; 33: 837-42.

34. Wojtukiewicz MZ, Hempel D, Sierko E, Tucker SC, Honn KV. Protease-activated receptors (PARs) - biology and role in cancer invasion and metastasis. Cancer Metastasis Rev 2015; 34: 775-96.

35. Wolczyk D, Zaremba-Czogalla M, Hryniewicz-Jankowska A, et al. TNF-alpha promotes breast cancer cell migration and enhances the concentration of membrane-associated proteases in lipid rafts. Cell Oncol 2016; 39: 353-63.

36. Zhu L, Yang S, He S, et al. Downregulation of ubiquitin-specific protease 14 (USP14) inhibits breast cancer cell proliferation and metastasis, but promotes apoptosis. J Mol Histol 2016; 47: 69-80.

37. Finger EC, Giaccia AJ. Hypoxia, inflammation, and the tumor microenvironment in metastatic disease. Cancer Metastasis Rev 2010; 29: 285-93.

38. Sledge GW, Mina LA. Rethinking the metastatic cas cade as a therapeutic target. Nat Rev Clin Oncol 2011 8: 325-32.

39. Geiger TR, Peeper DS. Metastasis mechanisms. Biochim Biophys Acta 2009; 1796: 293-308.

40. Hoon DSB, Ferris R, Tanaka R, Chong KK, Alix-Panabières $C$, Pantel K. Molecular mechanisms of metastasis. J Surg Oncol 2011; 103: 508-17.

41. Brooks SA, Lomax-Browne HJ, Carter TM, Kinch CE, Hall DMS. Molecular interactions in cancer cell metastasis. Acta Histochem 2010; 112: 3-25.

42. Liao D, Johnson RS. Hypoxia: a key regulator of angiogenesis in cancer. Cancer Metastasis Rev 2007; 26: 281-90.

43. Fox SB, Harris AL. Histological quantitation of tumour angiogenesis. APMIS 2004; 112: 413-30.

44. Valero C, Javierre E, García-Aznar JM, Gómez-Benito MJ. Numerical modelling of the angiogenesis process in wound contraction. Biomech Modeling Mechanobio 2013; 12: 349-60.
45. Goh V. Functional imaging of colorectal cancer angiogenesis. Lancet Oncol 2007; 8: 245-55.

46. Sacewicz I, Wiktorska M, Wysocki T, Niewiarowska J. Mechanisms of cancer angiogenesis. Postep Hig Med Dośw 2009; 63: 159-68.

47. Garmy-Susini B, Varner JA. Roles of integrins in tumor angiogenesis and lymphangiogenesis. Lymph Res Biol 2008; 6: 155-63.

48. Varner JA, Avraamides CJ, Garmy-Susini B. Integrins in angiogenesis and lymphangiogenesis. Nature Rev Cancer 2008; 8: 604-17.

49. Papetti M, Herman IM. Mechanisms of normal and tumor-derived angiogenesis. Am J Physiol Cell Physiol 2002; 282: C947-70.

50. Otrock ZK, Mahfouz RAR, Makarem JA, Shamseddine Al. Understanding the biology of angiogenesis: Review of the most important molecular mechanisms. Blood Cells Mol Dis 2007; 39: 212-20.

51. Strell C, Entschladen F. Extravasation of leukocytes in comparison to tumor cells. Cell Commun Signal 2008; 6: 10.

52. Hazan RB, Qiao RUI, Keren R, Badano I, Suyama K. Cadherin switch in tumor progression. Ann N Y Acad Sci 2004; 1014: 155-63.

53. Jeanes A, Gottardi CJ, Yap AS. Cadherins and cancer: how does cadherin dysfunction promote tumor progression? Oncogene 2008; 27: 6920-9.

54. Niessen CM, Leckband D, Yap AS. Tissue organization by cadherin adhesion molecules: dynamic molecular and cellular mechanisms of morphogenetic regulation. Physiol Rev 2011; 91: 691-731.

55. Tsanou E, Peschos D, Batistatou A, Charalabopoulos A Charalabopoulos K. The E-cadherin adhesion molecule and colorectal cancer. A global literature approach. Anticancer Res 2008; 28 (6A): 3815.

56. Christofori G, Wilgenbus P, Perl AK, Dahl U, Semb H. A causal role for E-cadherin in the transition from adenoma to carcinoma. Nature 1998; 392: 190-3.

57. Zheng Z, Pan J, Chu B, Wong YC, Cheung ALM, Tsao SW. Downregulation and abnormal expression of E-cadherin and beta-catenin in nasopharyngeal carcinoma: close association with advanced disease stage and lymph node metastasis. Human Pathol 1999; 30: 458-66.

58. Blok P, Craanen ME, Dekker W, Tytgat GNJ. Loss of E-cadherin expression in early gastric cancer. Histopathology 1999; 34: 410-5.

59. Kuniyasu $H$, Ellis LM, Evans DB, et al. Relative expression of e-cadherin and type iv collagenase genes predicts disease outcome in patients with resectable pancreatic carcinoma. Clin Cancer Res 1999; 5: 25-33.

60. Sulzer MA, Leers MP, van Noord JA, Bollen EC, Theunissen $\mathrm{PH}$. Reduced E-cadherin expression is associated with increased lymph node metastasis and unfavorable prognosis in non-small cell lung cancer. Am J Respir Crit Care Med 1998; 157: 1319.

61. Slaton JW, Inoue K, Perrotte P, et al. Expression levels of genes that regulate metastasis and angiogenesis correlate with advanced pathological stage of renal cell carcinoma. Am J Pathol 2001; 158: 735-43.

62. Wijnhoven B, Dinjens W, Pignatelli M. E-cadherin-catenin cell-cell adhesion complex and human cancer. $\mathrm{Br}$ J Surg 2000; 87: 992-1005.

63. Hazan RB, Phillips GR, Qiao RF, Norton L, Aaronson SA. Exogenous expression of $\mathrm{n}$-cadherin in breast cancer cells induces cell migration, invasion, and metastasis. J Cell Biol 2000; 148: 779-90.

64. Chiang SPH, Cabrera RM, Segall JE. Tumor cell intravasation. Am J Physiol Cell Physiol 2016; 311: C1-14. 
65. Wyckoff JB, Jones JG, Condeelis JS, Segall JE. A critical step in metastasis: in vivo analysis of intravasation at the primary tumor. Cancer Res 2000; 60: 2504-11.

66. Wolf K, Friedl P. Tumour-cell invasion and migration: diversity and escape mechanisms. Nature Rev Cancer 2003; 3: 362-74.

67. McCarthy JB, Furcht LT. Laminin and fibronectin promote the haptotactic migration of b16 mouse melanoma cells in vitro. J Cell Biol 1984; 98: 1474-80.

68. Dvorak HF, Sioussat TM, Brown LF, et al. Distribution of vascular permeability factor (vascular endothelial growth factor) in tumors: concentration in tumor blood vessels. J Exp Med 1991; 174: 1275-8.

69. Bockhorn M. Active versus passive mechanisms in metastasis: do cancer cells crawl into vessels, or are they pushed? Lancet Oncol 2007; 8: 444-8.

70. Bendas G, Borsig L. Cancer cell adhesion and metastasis: selectins, integrins, and the inhibitory potential of heparins. Int J Cell Biol 2012; 2012: 676731-10.

71. Gout S, Tremblay PL, Huot J. Selectins and selectin ligands in extravasation of cancer cells and organ selectivity of metastasis. Clin Exp Metastasis 2008; 25: 335-44.

72. Klemke $M$, Weschenfelder T, Konstandin MH, Samstag Y. High affinity interaction of integrin $\alpha 4 \beta 1$ (VLA-4) and vascular cell adhesion molecule 1 (VCAM-1) enhances migration of human melanoma cells across activated endothelial cell layers. J Cell Physiol 2007; 212: 368-74.

73. Stroka KM, Konstantopoulos K. Physical biology in cancer. 4. Physical cues guide tumor cell adhesion and migration. Am J Physiol Cell Physiol 2014; 306: C98-109.

74. Gassmann P, Haier J. The tumor cell-host organ interface in the early onset of metastatic organ colonisation. Clin Exp Metastasis 2008; 25: 171-81.

75. Glinskii OV, Huxley VH, Glinsky GV, Pienta KJ, Raz A, Glinsky VV. Mechanical entrapment is insufficient and intercellular adhesion is essential for metastatic cell arrest in distant organs. Neoplasia 2005; 7: 522-7.

76. Joyce JA, Pollard JW. Microenvironmental regulation of metastasis. Nat Rev Cancer 2009; 9: 239-52.

77. Koop S, Schmidt EE, MacDonald IC, et al. Independence of metastatic ability and extravasation: metastatic RAS-transformed and control fibroblasts extravasate equally well. Proc Natl Acad Sci USA 1996; 93: 11080-4.

78. Fidler IJ. Metastasis: quantitative analysis of distribution and fate of tumor emboli labeled with 125 I-5-iodo-2'-deoxyuridine. J Natl Cancer Inst 1970; 45 . 773-82.

79. Geho DH, Bandle RW, Clair T, Liotta LA. Physiological mechanisms of tumor-cell invasion and migration. Physiology 2005; 20: 194-200.

80. Guo W, Giancotti FG. Integrin signalling during tumour progression. Nat Rev Mol Cell Biol 2004; 5: 816-26.

81. Quail DF, Joyce JA. Microenvironmental regulation of tumor progression and metastasis. Nature Med 2013; 19: 1423-37.

82. E-P-selectins and colon carcinoma metastasis: first evidence for their crucial role in a clinically relevant model of spontaneous metastasis formation in the lung. Br J Cancer 2010; 102: 602-9.

83. Hiratsuka S, Goel S, Kamoun WS, et al. Endothelial focal adhesion kinase mediates cancer cell homing to discrete regions of the lungs via E-selectin up-regulation. Proc Natl Acad Sci USA 2011; 108: 3725-30.

84. Auguste P, Fallavollita L, Wang N, Burnier J, Bikfalvi A, Brodt $P$. The host inflammatory response promotes liver metastasis by increasing tumor cell arrest and extravasation. Am J Pathol 2007; 170: 1781-92.

85. Eichbaum C, Meyer AS, Wang N, et al. Breast cancer cell-derived cytokines, macrophages and cell adhesion: implications for metastasis. Anticancer Res 2011; 31: 3219-27.

86. Kawamura YI, Adachi Y, Curiel DT, et al. Therapeutic adenoviral gene transfer of a glycosyltransferase for prevention of peritoneal dissemination and metastasis of gastric cancer. Cancer Gene Therapy 2014; 21: 427-33.

87. Borsig L, Wong R, Feramisco J, Nadeau DR, Varki NM, Varki A. Heparin and cancer revisited: mechanistic connections involving platelets, P-selectin, carcinoma mucins, and tumor metastasis. Proc Natl Acad Sci USA 2001; 98: 3352-7.

88. Läubli H, Stevenson JL, Varki A, Varki NM, Borsig L. L-selectin facilitation of metastasis involves temporal induction of Fut7-dependent ligands at sites of tumor cell arrest. Cancer Res 2006; 66: 1536-42.

89. Miles FL, Pruitt FL, van Golen KL, Cooper CR. Stepping out of the flow: capillary extravasation in cancer metastasis. Clin Exp Metastasis 2008; 25: 305-24.

90. Strell C, Lang K, Niggemann B, Zaenker KS, Entschladen F. Surface molecules regulating rolling and adhesion to endothelium of neutrophil granulocytes and MDA-MB-468 breast carcinoma cells and their interaction. Cell Mol Life Sci 2007; 64: 3306-16.

91. Balkwill F. Cancer and the chemokine network. Nat Rev Cancer 2004; 4: 540-50.

92. Vandercappellen J, Van Damme J, Struyf S. The role of CXC chemokines and their receptors in cancer. Cancer Lett 2008; 267: 226-44.

93. Buchanan ME, Murphy E, Wagner SN, et al. Involvement of chemokine receptors in breast cancer metastasis. Nature 2001; 410: 50-6.

94. Jamieson WL, Shimizu S, D’Ambrosio JA, Meucci O, Fatatis A. CX3CR1 is expressed by prostate epithelial cells and androgens regulate the levels of $C X 3 C L 1 /$ fractalkine in the bone marrow: potential role in prostate cancer bone tropism. Cancer Res 2008; 68; 1715-22.

95. Shulby SA, Dolloff NG, Stearns ME, Meucci O, Fatatis A. CX3CR1-fractalkine expression regulates cellular mechanisms involved in adhesion, migration, and survival of human prostate cancer cells. Cancer Res 2004; 64: 4693-8.

96. Drell Iv TL, Joseph J, Lang K, Niggemann B, Zaenker KS, Entschladen F. Effects of neurotransmitters on the chemokinesis and chemotaxis of mda-mb-468 human breast carcinoma cells. Breast Cancer Res Treat 2003; 80: 63-70.

97. Entschladen F, Palm D, Niggemann B, Zaenker KS. The cancer's nervous tooth: considering the neuronal crosstalk within tumors. Semin Cancer Biol 2008; 18: 171-5.

98. Garofalo A, Chirivi RG, Foglieni C, et al. Involvement of the very late antigen 4 integrin on melanoma in interleukin 1-augmented experimental metastases. Cancer Res 1995; 55: 414-9.

99. Okahara H, Yagita H, Miyake K, Okumura K. Involvement of very late activation antigen 4 (VLA-4) and vascular cell adhesion molecule 1 (VCAM-1) in tumor necrosis factor alpha enhancement of experimental metastasis. Cancer Res 1994; 54: 3233.

100. Nangia-Makker P, Sarvis R, Visscher DW, Bailey-Penrod J, Raz A, Sarkar FH. Galectin-3 and L1 retrotransposons in human breast carcinomas. Breast Cancer Res Treat 1998; 49: 171-83. 
101. Mierke CT, Zitterbart DP, Kollmannsberger P, et al. Breakdown of the endothelial barrier function in tu mor cell transmigration. Biophys J 2008; 94: 2832-46.

102. Couture P, Paradis-Massie J, Oualha N, Thibault G. Adhesion and transcellular migration of neutrophils and B lymphocytes on fibroblasts. Exp Cell Res 2009; 315: 2192-206.

103. Garrido-Urbani S, Bradfield PF, Lee BPL, Imhof BA. Vascular and epithelial junctions: a barrier for leucocyte migration. Biochem Soc Trans 2008; 36: 203.

104. Petri B, Bixel MG. Molecular events during leukocyte diapedesis. FEBS J 2006; 273: 4399-407.

105. Voura EB, Sandig M, Siu CH. Cell-cell interactions during transendothelial migration of tumor cells. Microsc Res Tech 1998; 43: 265-75.

106. Qi J, Chen N, Wang J, Siu CH. Transendothelial migration of melanoma cells involves $\mathrm{N}$-cadherin-mediated adhesion and activation of the beta-catenin signaling pathway. Mol Biol Cell 2005; 16: 4386-97.

107. Brandt B, Heyder C, Gloria-Maercker E, et al. 3D-extravasation model - selection of highly motile and metastatic cancer cells. Semin Cancer Biol 2005; 15: 387-95.

108. Friedl PHA, Weigelin B. Interstitial leukocyte migration and immune function. Nat Immunol 2008; 9: 960-9.

109. Leppert D, Waubant E, Galardy R, Bunnett NW, Hauser SL. T cell gelatinases mediate basement membrane transmigration in vitro. J Immunol 1995; 154: 4379.

110. Kobayashi H, Boelte K, Lin PC. Endothelial cell adhesion molecules and cancer progression. Curr Med Chem 2007; 14: 377-86.

111. Li DM, Feng YM. Signaling mechanism of cell adhesion molecules in breast cancer metastasis: potential therapeutic targets. Breast Cancer Res Treat 2011; 128 . 7-21.

112. Yasmin-Karim S, King MR, Messing EM, Lee YF. E-selectin ligand-1 controls circulating prostate cancer cell rolling/adhesion and metastasis. Oncotarget 2014; 5: 12097-110.

113. Desgrosellier JS, Cheresh DA. Integrins in cancer: biological implications and therapeutic opportunities. Nat Rev Cancer 2010; 10: 9-22.

114. Läubli H, Borsig L. Selectins promote tumor metastasis. Semin Cancer Biol 2010; 20: 169-77.

115 . Hynes RO. Integrins: bidirectional, allosteric signaling machines. Cell 2002; 110: 673-87.

116. Lipscomb EA, Dugan AS, Rabinovitz I, Mercurio AM. Use of RNA interference to inhibit integrin (alpha6beta4)-mediated invasion and migration of breast carcinoma cells. Clin Exp Metastasis 2003; 20: 569-76.

117. Dedhar S, Saulnier R, Nagle R, Overall CM. Specific alterations in the expression of alpha 3 beta 1 and alpha 6 beta 4 integrins in highly invasive and metastatic variants of human prostate carcinoma cells selected by in vitro invasion through reconstituted basement membrane. Clin Exp Metastasis 1993; 11: 391-400.

118. Pouliot N, Nice EC, Burgess AW. Laminin-10 mediates basal and EGF-stimulated motility of human colon carcinoma cells via alpha(3)beta(1) and alpha(6)beta(4) integrins. Exp Cell Res 2001; 266: 1-10.

119. Natali PG, Nicotra MR, Bartolazzi A, Cavaliere R, Bigotti A. Integrin expression in cutaneous malignant melanoma: association of the alpha 3/beta 1 heterodimer with tumor progression. Int J Cancer 1993; 54: 68-72.

120. Hieken TJ, Farolan M, Ronan SG, Shilkaitis A, Wild L, Das Gupta TK. beta3 integrin expression in melanoma predicts subsequent metastasis. J Surg Res 1996; 63: 169-73.
121. Felding-Habermann B, O'Toole TE, Smith JW, et al. Integrin activation controls metastasis in human breast cancer. Proc Natl Acad Sci USA 2001; 98: 1853-8.

122. Uings IJ, Farrow SN. Cell receptors and cell signalling. Mol Pathol 2000; 53: 295-9.

123. Khatib AM, Kontogiannea M, Fallavollita L, Jamison B, Meterissian S, Brodt P. Rapid induction of cytokine and E-selectin expression in the liver in response to metastatic tumor cells. Cancer Res 1999; 59: 1356-61.

124. Kansas GS. Selectins and their ligands: current concepts and controversies. Blood 1996; 88: 3259-87.

125. Kaas Q, Ehrenmann F, Lefranc MP. IG, TR and IgSF, MHC and MhcSF: what do we learn from the IMGT Colliers de Perles? Brief Funct Genom Proteom 2007; 6: 253-64.

126. Lee G, Zhu M, Ge B, Potzold S. Widespread expressions of immunoglobulin superfamily proteins in cancer cells. Cancer Immunol Immunother 2012; 61: 89-99.

127. Touvier M, Fezeu L, Ahluwalia N, et al. Pre-diagnostic levels of adiponectin and soluble vascular cell adhesion molecule-1 are associated with colorectal cancer risk. World J Gastroenterol 2012; 18: 2805-12.

128. Regidor PA, Callies R, Regidor M, Schindler AE. Expression of the cell adhesion molecules ICAM-1 and VCAM-1 in the cytosol of breast cancer tissue, benign breast tissue and corresponding sera. Eur J Gynaecol Oncol 1998; 19: 377-83.

129. Chambers AF, Groom AC, MacDonald IC. Dissemination and growth of cancer cells in metastatic sites. Nat Rev Cancer 2002; 2: 563-72.

130. Chakrabarti S, Patel KD. Matrix metalloproteinase-2 (MMP-2) and MMP-9 in pulmonary pathology. Exp Lung Res 2005; 31: 599-621.

131. Ribatti D, Mangialardi G, Vacca A. Stephen Paget and the 'seed and soil' theory of metastatic dissemination. Clin Exp Med 2006; 6: 145-9.

132. Demaria S, Pikarsky E, Karin M, et al. Cancer and inflammation: promise for biologic therapy. J Immunother 2010; 33: 335-51

133. Guarino V, Castellone MD, Avilla E, Melillo RM. Thyroid cancer and inflammation. Mol Cell Endocrinol 2010; 321: 94-102.

134. Hussain SP, Harris CC. Inflammation and cancer: an ancient link with novel potentials. Int J Cancer 2007; 121: 2373-80

135. Mantovani A, Pierotti MA. Cancer and inflammation: a complex relationship. Cancer Lett 2008; 267: 180-1.

136. Riegler G, Tartaglione MT, Bossa F. Ulcerative colitis and cancer. Tech Coloproctol 1999; 3: 189-91.

137. Weiss U. Inflammation. Nature 2002; 420: 845.

138. Weiss U. Inflammation. Nature 2008; 454: 427.

139. Schulte D, Vestweber D, Zarbock A, et al. Stabilizing the VE-cadherin-catenin complex blocks leukocyte extravasation and vascular permeability. EMBO J 2011; 30: 4157-70.

140. Wang S, Cao C, Chen Z, et al. Pericytes regulate vascular basement membrane remodeling and govern neutrophil extravasation during inflammation. PLoS One 2012; 7: e45499.

141. Zuchtriegel G, Uhl B, Puhr-Westerheide D, et al. Platelets guide leukocytes to their sites of extravasation. PLoS Biol 2016; 14: e1002459.

142. Wright RD, Cooper D. Glycobiology of leukocyte trafficking in inflammation. Glycobiology 2014; 24: 1242-51.

143. Ludwig RJ, Zollner TM, Santoso S, et al. Junctional adhesion molecules (JAM)-B and -C contribute to leukocyte extravasation to the skin and mediate cutaneous inflammation. J Investig Dermatol 2005; 125: 969-76. 
144. Vestweber D. Novel insights into leukocyte extravasation. Curr Opin Hematol 2012; 19: 212-7.

145. Banerjee P, Jana S, Chakraborty S, Swarnakar S. Inflammation and MMPs in alcohol-induced liver diseases and protective action of antioxidants. Indian J Biochem Biophys 2013; 50: 377-86.

146. Bruschi F, Bianchi C, Fornaro M, et al. Matrix metalloproteinase (MMP)-2 and MMP-9 as inflammation markers of Trichinella spiralis and Trichinella pseudospiralis infections in mice. Parasite Immunol 2014; 36: 540-9.

147. Väänänen $T$, Hämäläinen $M$, Koskinen $A$, et al. YKL-40 is associated with inflammation and MMPs in osteoarthritis. Osteoarthr Cartilage 2016; 24: S78-9.

148. Bulbule A, Saraswati S, Kundu GC. Status of research on matrix metalloproteinases (MMPs) in India. Exp Opin Ther Targets 2011; 15: 671-5.

149. Nathan C, Ding A. Nonresolving inflammation. Cell 2010; 140: 871-82.

150. Seiler R, Thalmann GN, Fleischmann A. MMP-2 and MMP-9 in lymph-node-positive bladder cancer. J Clin Pathol 2011; 64: 1078-82.

151. Cox G, O’Byrne KJ. Matrix metalloproteinases and cancer. Anticancer Res 2001; 21: 4207-19.

152. Gialeli C, Theocharis AD, Karamanos NK. Roles of matrix metalloproteinases in cancer progression and their pharmacological targeting. FEBS J 2011; 278: 16-27.

153. Hadler-Olsen E, Winberg JO, Uhlin-Hansen L. Matrix metalloproteinases in cancer: their value as diagnostic and prognostic markers and therapeutic targets. Tumor Biol 2013; 34: 2041-51.

154. Apidianakis Y, Ferrandon D. Model Organisms in Inflammation and Cancer. Frontiers Media SA, Lausanne, Switzerland 2014.

155. Grivennikov SI, Greten FR, Karin M. Immunity, inflammation, and cancer. Cell 2010; 140: 883-99.

156. Werb Z, Coussens LM. Inflammation and cancer. Nature 2002; 420: 860-7.

157. Hanahan D, Weinberg RA. Hallmarks of cancer: the next generation. Cell 2011; 144: 646-74.

158. Capece D, Fischietti M, Verzella D, et al. The inflammatory microenvironment in hepatocellular carcinoma a pivotal role for tumor-associated macrophages. BioMed Res Int 2013; 2013: 187204-15.

159. Weitzenfeld P, Meron N, Leibovich-Rivkin T, Meshel T, Ben-Baruch A. Progression of luminal breast tumors is promoted by menage a trois between the inflammatory cytokine TNF[alpha] and the hormonal and growth-supporting arms of the tumor microenvironment. Mediators Inflamm 2013; 2013; 720536.

160. Coveñas R, Muñoz M. Cancer progression and substance P. Histol Histopathol 2014; 29: 881-90.

161. Muñoz M, Coveñas R. Involvement of substance $P$ and the NK-1 receptor in cancer progression. Peptides 2013; 48: 1-9.

162. Pena MMO, Zhang Y, Davis C, et al. Abstract C21: IL-33 promotes growth and liver metastasis of colorectal cancer in mice by remodeling the tumor microenvironment and inducing angiogenesis. Cancer Res 2016; 76 (15 Suppl): C21.

163. Liu X, Zhu L, Lu X, et al. IL-33/ST2 pathway contributes to metastasis of human colorectal cancer. Biochem Biophys Res Commun 2014; 453: 486-92.

164. Bastiaannet E, Sampieri K, Dekkers OM, et al. Use of aspirin postdiagnosis improves survival for colon cancer patients. Br J Cancer 2012; 106: 1564-70.
165. Lim WY, Chuah KL, Eng P, et al. Aspirin and non-aspirin non-steroidal anti-inflammatory drug use and risk of lung cancer. Lung Cancer 2012; 77: 246-51.

166. Mione M, Zon LI. Cancer and inflammation: an aspirin a day keeps the cancer at bay. Curr Biol 2012; 22: R522-5.

167. Björklund M, Koivunen E. Gelatinase-mediated migration and invasion of cancer cells. BBA Rev Cancer 2005; 1755: 37-69.

168. Kessenbrock K, Plaks V, Werb Z. Matrix metalloproteinases: regulators of the tumor microenvironment. Cell 2010; 141: 52-67.

169. Verma RP, Hansch C. Matrix metalloproteinases (MMPs): chemical-biological functions and (Q)SARs. Bioorgan Med Chem 2007; 15: 2223-68.

170. Page-McCaw A, Ewald AJ, Werb Z. Matrix metalloproteinases and the regulation of tissue remodelling. Nat Rev Mol Cell Biol 2007; 8: 221-33.

171. Parks WC, Shapiro SD. Matrix metalloproteinases in lung biology. Respir Res 2001; 2: 10-9.

172. Egeblad $M$, Werb Z. New functions for the matrix metalloproteinases in cancer progression. Nat Rev Cancer 2002; 2: 161-74.

173. Alexander CM, Hansell EJ, Behrendtsen O, et al. Expression and function of matrix metalloproteinases and their inhibitors at the maternal-embryonic boundary during mouse embryo implantation. Development 1996; 122: 1723-36.

174. Zhang XF, Zhang Y, Zhang XH, et al. Clinical significance of neutrophil gelatinase-associated lipocalin (NGAL) expression in primary rectal cancer. BMC Cancer 2009; 9: 134.

175. Kotra LP, Zhang L, Fridman R, Orlando R, Mobashery S. $\mathrm{N}$-Glycosylation pattern of the zymogenic form of human matrix metalloproteinase-9. Bioorg Chem 2002; 30: 356-70.

176. Devarajan P, Johnston JJ, Ginsberg SS, Wart HEV, Berliner N. Structure and expression of neutrophil gelatinase cDNA. Identity with type IV collagenase from HT1080 cells. J Biol Chem 1992; 267: 25228-32.

177. Schwingshackl A, Duszyk M, Brown N, Moqbel R. Human eosinophils release matrix metalloproteinase-9 on stimulation with TNF-alpha. J Allergy Clin Immunol 1999; 104: 983-90.

178. Frisch SM, Morisaki JH. Positive and negative transcriptional elements of the human type IV collagenase gene. Mol Cell Biol 1990; 10: 6524-32.

179. Fernandez-Patron C, Martinez-Cuesta MA, Salas E, et al. Differential regulation of platelet aggregation by matrix metalloproteinases-9 and -2 . Thromb Haemostasis 1999; 82: 1730.

180. Vu TH. Don't mess with the matrix. Nat Genet 2001; 28: 202-3.

181. Chen El, Kridel SJ, Howard EW, Li W, Godzik A, Smith JW. A unique substrate recognition profile for matrix metalloproteinase-2. J Biol Chem 2002; 277 : 4485-91.

182. Kridel SJ, Chen E, Kotra LP, Howard EW, Mobashery S, Smith JW. Substrate hydrolysis by matrix metalloproteinase-9. J Biol Chem 2001; 276: 20572-8.

183. Backstrom JR, Tökés ZA. The $84-k D a$ form of human matrix metalloproteinase-9 degrades substance $P$ and gelatin. J Neurochem 1995; 64: 1312-8.

184. Birkedal-Hansen $\mathrm{H}$. Role of matrix metalloproteinases in human periodontal diseases. J Periodontol 1993; 64 (5 Suppl): 474-84

185. Sato H, Kinoshita T, Takino T, Nakayama K, Seiki M. Activation of a recombinant membrane type 1-ma- 
trix metalloproteinase (MT1-MMP) by furin and its interaction with tissue inhibitor of metalloproteinases (TIMP)-2. FEBS Lett 1996; 393: 101-4.

186. Yana I, Weiss SJ. Regulation of membrane type-1 matrix metalloproteinase activation by proprotein convertases. Mol Biol Cell 2000; 11: 2387-401.

187. Nagase H, Visse R, Murphy G. Structure and function of matrix metalloproteinases and TIMPs. Cardiovasc Res 2006; 69: 562-73.

188. Ravi A, Garg P, Sitaraman SV. Matrix metalloproteinases in inflammatory bowel disease: boon or a bane? Inflamm Bowel Dis 2007; 13: 97-107.

189. O'Connell JP, Willenbrock F, Docherty AJ, Eaton D, Murphy $\mathrm{G}$. Analysis of the role of the $\mathrm{COOH}$-terminal domain in the activation, proteolytic activity, and tissue inhibitor of metalloproteinase interactions of gelatinase B. J Biol Chem 1994; 269: 14967-73.

190. Mohan R, Chintala SK, Jung JC, et al. Matrix metalloproteinase gelatinase B (MMP-9) coordinates and effects epithelial regeneration. J Biol Chem 2002; 277: 2065-72.

191. Mohan MJ, Seaton T, Mitchell J, et al. The tumor necrosis factor-alpha converting enzyme (TACE): a unique metalloproteinase with highly defined substrate selectivity. Biochemistry 2002; 41: 9462-9.

192. Cullen B, Smith R, McCulloch E, Silcock D, Morrison L. Mechanism of action of PROMOGRAN, a protease modulating matrix, for the treatment of diabetic foot ulcers. Wound Repair Regeneration 2002; 10: 16-25.

193. Wiegand C, Schönfelder U, Abel M, Ruth P, Kaatz M, Hipler UC. Protease and pro-inflammatory cytokine concentrations are elevated in chronic compared to acute wounds and can be modulated by collagen type I in vitro. Arch Dermatol Res 2010; 302: 419-28.

194. Van den Steen PE, Dubois B, Nelissen I, Rudd PM Dwek RA, Opdenakker G. Biochemistry and molecula biology of gelatinase B or matrix metalloproteinase- 9 (MMP-9). Crit Rev Biochem Mol Biol 2002; 37: 375-536.

195. O'Connor TM, O'Connell J, O'Brien DI, Goode T, Bredin CP, Shanahan F. The role of substance $P$ in inflammatory disease. J Cell Physiol 2004; 201: 167-80.

196. Nissinen L, Kähäri VM. Matrix metalloproteinases in inflammation. Biochim Biophys Acta 2014; 1840: 2571-80.

197. Nagase H, Woessner JJF. Matrix metalloproteinases. J Biol Chem 1999; 274: 21491-4.

198. Borregaard N. Development of neutrophil granule diversity. Ann N Y Acad Sci 1997; 832: 62-8.

199. Cowland JB, Borregaard N. The individual regulation of granule protein mRNA levels during neutrophil maturation explains the heterogeneity of neutrophil granules. J Leukoc Biol 1999; 66: 989-95.

200. Chandrashekar N, Selvamani A, Subramanian R, Pan di A, Thiruvengadam D. Baicalein inhibits pulmonary carcinogenesis-associated inflammation and interferes with COX-2, MMP-2 and MMP-9 expressions in-vivo. Toxicol Appl Pharmacol 2012; 261: 10-21.

201. Opdenakker G, Philippe EV, Dubois B, et al. Gelatinase $B$ functions as regulator and effector in leukocyte biology. J Leukoc Biol 2001; 69: 851-9.

202. Yu Q, Stamenkovic I. Cell surface-localized matrix metalloproteinase- 9 proteolytically activates TGF-beta and promotes tumor invasion and angiogenesis. Genes Develop 2000; 14: 163-76.

203. Schönbeck U, Mach F, Libby P. Generation of biologically active IL-1 beta by matrix metalloproteinases: a novel caspase-1-independent pathway of IL-1 beta processing. J Immunol 1998; 161: 3340-6.
204. Khokha R, Murthy A, Weiss A. Metalloproteinases and their natural inhibitors in inflammation and immunity. Nat Rev Immunol 2013; 13: 649-65.

205. Nathan C. Points of control in inflammation. Nature 2002; 420: 846-52

206. Lee HM, Ciancio SG, Tüter G, Ryan ME, Komaroff E, Golub LM. Subantimicrobial dose doxycycline efficacy as a matrix metalloproteinase inhibitor in chronic periodontitis patients is enhanced when combined with a non-steroidal anti-inflammatory drug. J Periodontol 2004; 75: 453-63.

207. Sierevogel M, Pasterkamp G, Kleijn D, Strauss B. Matrix metalloproteinases: a therapeutic target in cardiovas cular disease. Curr Pharm Design 2003; 9: 1033-40.

208. Sorsa T, Ramamurthy NS, Vernillo AT, et al. Functional sites of chemically modified tetracyclines: inhibition of the oxidative activation of human neutrophil and chicken osteoclast pro-matrix metalloproteinases. J Rheumatol 1998; 25: 975-82.

209. Seftor REB, Seftor EA, De Larco JE, et al. Chemically modified tetracyclines inhibit human melanoma cell invasion and metastasis. Clin Exp Metastasis 1998; 16: 217-25.

210. Cianfrocca M, Cooley TP, Lee JY, et al. Matrix metalloproteinase inhibitor COL-3 in the treatment of AIDS-related Kaposi's sarcoma: a phase I AIDS malignancy consortium study. J Clin Oncol 2002; 20: 153-9.

211. Coussens LM, Werb Z. Inflammation and cancer. Nature 2002; 420: 860-7.

212. Radisky ES, Radisky DC. Matrix metalloproteinase-induced epithelial-mesenchymal transition in breast cancer. J Mammary Gland Biol Neoplasia 2010; 15: 201-12.

213. Baruch RR, Melinscak H, Lo J, Liu Y, Yeung O, Hurta RAR. Altered matrix metalloproteinase expression associated with oncogene-mediated cellular transformation and metastasis formation. Cell Biol Int 2001; 25: 411-20.

214. Guo CB, Wang S, Deng C, Zhang DL, Wang FL, Jin XQ. Relationship between matrix metalloproteinase 2 and lung cancer progression. Mol Diag Ther 2007; 11: 183-92.

215. Mook ORF, Frederiks WM, Van Noorden CJF. The role of gelatinases in colorectal cancer progression and metastasis. Biochim Biophys Acta 2004; 1705: 69-89.

216. van den Oord JJ, Paemen L, Opdenakker G, de WolfPeeters C. Expression of gelatinase B and the extracellular matrix metalloproteinase inducer EMMPRIN in benign and malignant pigment cell lesions of the skin. Am J Pathol 1997; 151: 665-70.

217. Pacheco MM, Mourao M, Mantovani EB, Nishimoto IN, Mitzi Brentani M. Expression of gelatinases A and B, stromelysin-3 and matrilysin genes in breast carcinomas: clinico-pathological correlations. Clin Exp Metastasis 1998; 16: 577-85.

218. Scorilas A, Karameris A, Arnogiannaki N, et al. Overexpression of matrix-metalloproteinase- 9 in human breast cancer: a potential favourable indicator in node-negative patients. Br J Cancer 2001; 84: 1488-96.

219. Takeha S, Fujiyama Y, Bamba T, Sorsa T, Nagura H, Ohtani H. Stromal expression of MMP-9 and urokinase receptor is inversely associated with liver metastasis and with infiltrating growth in human colorectal cancer: a novel approach from immune/inflammatory aspect. Jap J Cancer Res 1997; 88: 72-81.

220. Zeng ZS, Huang Y, Cohen AM, Guillem JG. Prediction of colorectal cancer relapse and survival via tissue RNA levels of matrix metalloproteinase-9. J Clin Oncol 1996; 14: 3133-40. 
221. Vihinen P, Kähäri VM. Matrix metalloproteinases in cancer: prognostic markers and therapeutic targets. Int J Cancer 2002; 99: 157-66.

222. Deryugina El, Quigley JP. Matrix metalloproteinases and tumor metastasis. Cancer Metastasis Rev 2006; 25: 9-34.

223. Murphy G. The ADAMs: signalling scissors in the tumour microenvironment. Nat Rev Cancer 2008; 8: 932-41.

224. Koshikawa N, Giannelli G, Cirulli V, Miyazaki K, Quaranta V. Role of cell surface metalloprotease MT1-MMP in epithelial cell migration over laminin-5. J Cell Biol 2000; 148: 615-24.

225. Torre C, Wang SJ, Xia W, Bourguignon LYW. Reduction of hyaluronan-CD44-mediated growth, migration, and cisplatin resistance in head and neck cancer due to inhibition of Rho kinase and PI-3 kinase signaling. Arch Otolaryngol Head Neck Surg 2010; 136: 493-501.

226. Baciu PC, Suleiman EA, Deryugina EI, Strongin AY. Membrane type-1 matrix metalloproteinase (MT1MMP) processing of pro-alphav integrin regulates cross-talk between alphavbeta3 and alpha2beta1 integrins in breast carcinoma cells. Exp Cell Res 2003; 291: 167-75.

227. Fukushima Y, Ohnishi T, Arita N, Hayakawa T, Sekiguchi K. Integrin alpha3beta1-mediated interaction with laminin-5 stimulates adhesion, migration and invasion of malignant glioma cells. Int J Cancer 1998; 76: 63-72.

228. Werb Z. ECM and Cell Surface Proteolysis: Regulating Cellular Ecology. Elsevier Inc 1997; 439-42.

229. Morozevich G, Kozlova N, Cheglakov I, Ushakova N, Berman A. Integrin $\alpha 5 \beta 1$ controls invasion of human breast carcinoma cells by direct and indirect modulation of MMP-2 collagenase activity. Cell Cycle 2009; 8: 2219-25.

230. Muñoz M, Coveñas R. Safety of neurokinin-1 receptor antagonists. Expert Opin Drug Saf 2013; 12: 673-85.

231. Pernow B. Distribution of substance $P$ in the central and peripheral nervous system. Nature 1953; 171: 746-7.

232. Sioka C, Kyritsis AP. Central and peripheral nervous system toxicity of common chemotherapeutic agents. Cancer Chemother Pharmacol 2009; 63: 761-7.

233. Blum AM, Elliott DE, Metwali A, Li J, Qadir K, Weinstock JV. Substance $P$ regulates somatostatin expression in inflammation. J Immunol 1998; 161: 6316-22.

234. Ringel Y, Carroll IM, Palsson OS, Sartor RB. S1249 substance $P$ and its mucosal receptors - possible mediators of inflammation and noxious sensation in irritable bowel syndrome. Gastroenterology 2009; 136: A-221-2.

235. Garcia-Recio S, Gascón P. Biological and pharmacological aspects of the NK1-receptor. BioMed Res Int 2015; 2015: 495704

236. Bhatia M. Hydrogen sulfide and substance $P$ in inflammation. Antioxid Redox Signal 2010; 12: 1191-202.

237. Killough SA, Lundy FT, Irwin CR. Substance P expres sion by human dental pulp fibroblasts: a potential role in neurogenic inflammation. J Endod 2009; 35: 73-7.

238. Luber-Narod J, Austin-Ritchie T, Hollins IC, et al. Role of substance $P$ in several models of bladder inflammation. Urol Res 1997; 25: 395-9.

239. Payan DG. Neuropeptides and inflammation: the role of substance P. Ann Rev Med 1989; 40: 341-52.

240. Rodriguez-Grande B, Blackabey V, Gittens B, Pinteaux E, Denes A. Loss of substance $P$ and inflammation precede delayed neurodegeneration in the substantia nigra after cerebral ischemia. Brain Behav Immun 2013; 29: 51-61.
241. Kabashima H, Nagata K, Maeda K, lijima T. Involvement of substance P, mast cells, TNF-alpha and ICAM-1 in the infiltration of inflammatory cells in human periapical granulomas. J Oral Pathol Med 2002; 31: 175-80.

242. Khan MM, Douglas SD, Benton TD. Substance P-neurokinin-1 receptor interaction upregulates monocyte tissue factor. J Neuroimmunol 2012; 242: 1-8.

243. Mascetta G, di Mola FF, Tavano F, et al. Substance P and neprilysin in chronic pancreatitis. Eur Surg Res 2012; 48: 131-8.

244. Lieb K, Schaller H, Bauer J, Berger M, Schulze-Osthoff $\mathrm{K}$, Fiebich BL. Substance $\mathrm{P}$ and histamine induce interleukin-6 expression in human astrocytoma cells by a mechanism involving protein kinase $\mathrm{C}$ and nuclear factor-IL-6. J Neurochem 1998; 70: 1577-83.

245. Saban MR, Saban R, Bjorling D, Haak-Frendscho M. Involvement of leukotrienes, TNF-alpha, and the LFA-1/ ICAM-1 interaction in substance P-induced granulocyte infiltration. J Leukoc Biol 1997; 61: 445-51.

246. Ansel JC, Brown JR, Payan DG, Brown MA. Substance P selectively activates TNF-alpha gene expression in murine mast cells. J Immunol 1993; 150: 4478-85.

247. Li J, Mahiouz DL, Farthing PM, Haskard DO, Thornhill $\mathrm{MH}$. Heterogeneity of ICAM-1 expression, and cytokine regulation of ICAM-1 expression, in skin and oral keratinocytes. J Oral Pathol Med 1996; 25: 112-8.

248. Matis WL, Lavker RM, Murphy GF. Substance P induces the expression of an endothelial-leukocyte adhesion molecule by microvascular endothelium. J Investig Dermatol 1990; 94: 492-5.

249. Halliday DA, McNeil JD, Betts WH, Scicchitano R. A role for the C-terminal fragment of substance P, SP 7-11 in the pathogenesis of arthritis. Regulatory Peptides 1993; 46: 195-7.

250. Chen XY, Ru GQ, Ma YY, et al. High expression of substance $P$ and its receptor neurokinin-1 receptor in colorectal cancer is associated with tumor progression and prognosis. Onco Targets Ther 2016; 9: 3595-602.

251. Ma J, Yuan S, Cheng J, Kang S, Zhao W, Zhang J. Substance $P$ promotes the progression of endometrial adenocarcinoma. Int J Gynecol Cancer 2016; 26: 845-50.

252. Muñoz M, González-Ortega A, Coveñas R. The NK-1 receptor is expressed in human leukemia and is involved in the antitumor action of aprepitant and other NK-1 receptor antagonists on acute lymphoblastic leukemia cell lines. Investig New Drugs 2012; 30: 529-40.

253. Muñoz M, González-Ortega A, Rosso M, et al. The substance $P$ /neurokinin-1 receptor system in lung cancer: focus on the antitumor action of neurokinin-1 receptor antagonists. Peptides 2012; 38: 318-25.

254. Li X, Ma G, Ma Q, et al. Neurotransmitter substance $P$ mediates pancreatic cancer perineural invasion via NK-1R in cancer cells. Mol Cancer Res 2013; 11: 294302.

255. Nowicki M, Ostalska-Nowicka D, Kondraciuk B, Miskowiak $B$. The significance of substance $P$ in physiological and malignant haematopoiesis. J Clin Pathol 2007; 60: 749-55.

256. Muñoz $M$, Rosso $M$, Coveñas R. A new frontier in the treatment of cancer: NK-1 receptor antagonists. Curr Med Chem 2010; 17: 504-16.

257. Friess H, Zhu Z, Liard V, et al. Neurokinin-1 receptor expression and its potential effects on tumor growth in human pancreatic cancer. Labor Investig 2003; 83: 731-42.

258. Lewis KM, Harford-Wright E, Vink R, Nimmo AJ, Ghabriel MN. Walker 256 tumour cells increase substance $P$ 
immunoreactivity locally and modify the properties of the blood-brain barrier during extravasation and brain invasion. Clin Exp Metastasis 2013; 30: 1-12.

259. Vilisaar J, Kawabe K, Braitch M, et al. Reciprocal regulation of substance $P$ and IL-12/IL-23 and the associated cytokines, IFN $\gamma /$ IL-17: a perspective on the relevance of this interaction to multiple sclerosis. J Neuroimm Pharmacol 2015; 10: 457-67.

260. Dickerson C, Undem B, Bullock B, Winchurch RA. Neuropeptide regulation of proinflammatory cytokine responses. J Leukoc Biol 1998; 63: 602-5.

261. Nakamura M, Chikama T, Nishida T. Up-regulation of integrin alpha 5 expression by combination of substance $P$ and insulin-like growth factor- 1 in rabbit corneal epithelial cells. Biochem Biophys Res Commun 1998; 246: 777-82. 